Stratigraphy, Morphology, and Paleoecology of a Fossil Peccary Herd From Western Kentucky

By WARREN I. FINCH, FRANK C. WHITMORE, JR., and JOHN D. SIMS

GE OLOGICAL S URVEY PR OFE S I O N A L P A P E R 790

Work done in part in cooperation with the

Kentucky Geological Survey

Nature of the death and burial of the herd and comparison with other fossil peccary herds of North America

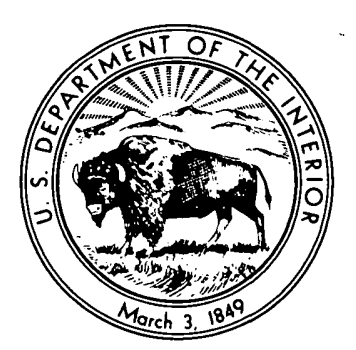




\section{UNITED STATES DEPARTMENT OF THE INTERIOR}

ROGERS C. B. MORTON, Secretary

GEOLOGICAL SURVEY

V. E. McKelvey, Director

Library of Congress catalog-card No. 72-600269

For sale by the Superintendent of Documents, U.S. Government Printing Office Washington, D.C. 20402 - Price 70 cents (paper cover)

Stock Number 2401-00248 


\section{CONTENTS}

Abstract.

Introduction..

Acknowledgments

Geologic setting.

Silt stratigraphy.

Silt petrology

Mineralogy and size analyses

Interpretation.

Silt fabric and paleowind directions

Fossils..

Platygonus compressus Le Conte 1848.

Positions of the skeletons..

Skeleton 1 .

Skeleton 2

Skeleton 3

Skeleton 4

Skeleton 5 .

\begin{tabular}{|c|c|}
\hline Ige & \\
\hline & Fossils-Continued \\
\hline 1 & Platygonus compressus Le Conte 1848 -Continued \\
\hline 1 & Composition and inferred habits of the herd.. \\
\hline 2 & Other herds of Platygonus compressus............... \\
\hline 2 & Denver, Colo., herd \\
\hline 4 & Goodland, Kans., herd.. \\
\hline 7 & Sandusky County, Ohio, herd.. \\
\hline 8 & Reading, Ohio, herd... \\
\hline 8 & Columbus, Ohio, herd.. \\
\hline 11 & Belding, Mich., herd... \\
\hline 12 & Gainesville, N.Y., herd... \\
\hline 12 & Pittsford?, N.Y., herd \\
\hline 12 & Size distribution in Platygonus compressus........ \\
\hline 14 & (1) \\
\hline 15 & Age of fossils...... \\
\hline 16 & Paleoecology and the death of the herd... \\
\hline 17 & 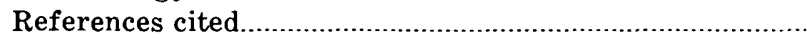 \\
\hline
\end{tabular}

Page

17

18

18

19

19

19

19

20

20

20

20

23

23

23

24

\section{ILLUSTRATIONS}

FIGURE 1. Map of Hickman $7 \frac{1}{2}$-minute quadrangle, showing the fossil peccary locality in western Kentucky

2. Section showing stratigraphic setting of fossil peccaries in Roxana Silt at White's gravel pit...

3. Chart showing correlation of silt units at the pecary locality with the classification of the Wiscons Illinois

4. Graphs showing X-ray mineralogy, microscopically visible carbonate content, and $\phi$-mean of samples 1-18.....

5. Graph showing mean and standard deviation of clay-mineral content of silt from peccary locality.

6. Silt-fabric rose diagrams for Roxana Silt and basal 7 feet of Peoria Loess.

7. Full-circle wind rose diagram based on readings of directions from which wind blew at Barkley Field, Paducah, Ky., and semicircle wind rose of strike directions of same wind data.

8. Silt-fabric rose diagram for samples from peccary zone......

9. Plan view and section showing relative position of the five peccary skeletons

10-13. Photographs of peccary Platygonus compressus:

10. Skeleton 1

11. Skeleton 2 and posterior part of skeleton 3

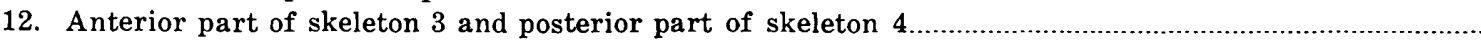

13. Parts of skeleton 4 and skeleton $\mathbf{5}$.

Page

\section{TABLES}

TABLE 1. Measurements of skulls, mandibles, and teeth of Platygonus compressus from near Hickman, Ky., and Denver, Colo

2. Measurements of postcranial skeletons of Platygonus compressus from near Hickman, Ky., and Denver, Colo.

3. Measurements indicative of stature of Platygonus compressus. 


\title{
STRATIGRAPHY, MORPHOLOGY, AND PALEOECOLOGY OF A FOSSIL PECGARY HERD FROM WESTERN KENTUCKY
}

\author{
By Warren I. Finch, Frank C. Whitmore, Jr., and John D. Sims
}

\section{ABSTRACT}

Fossils of a herd of five adult peccaries, Platygonus compressus Le Conte, were discovered in May 1967 beneath about 65 feet $(20 \mathrm{~m})$ of silt. Their position was $4-5.5$ feet $(1.2-1.6$ $m$ ) above the base of the Roxana Silt of Wisconsinan age, which rests unconformably on continental gravel deposits of Pliocene(?) and Pleistocene age. The peccaries were confined to an area 3 feet wide and 11 feet long $(1$ by $3.3 \mathrm{~m})$ and lay with their heads pointed southeastward on an indistinct upward-sloping surface. This surface marks a gradational change from mixed alluvial and eolian silt below to entirely eolian silt above. X-ray mineralogic and size analyses and thin-section examinations of samples from the full 11 feet $(3.3 \mathrm{~m})$ of Roxana and the basal 7 feet $(2.1 \mathrm{~m})$ of the overlying Peoria Loess confirm the field stratigraphic relations of the two units and indicate several probable paleosols. Silt fabric, based on orientation of quartz grains, shows maximums that fit the dominant southwest and northwest presentday wind directions. Morphology and position of each skeleton are described in detail. The poses of the skeletons indicate that the herd died quietly and was buried quickly, probably overwhelmed in a duststorm as they walked southeastward up a path from the river with their backs to the world. Probably the animals either died of cold or were smothered while comatose because of cold, and they were buried almost immediately. Size distribution of other Platygonus compressus herds is compared with that of the Hickman herd. Mollusca associated with the skeletons have a radiocarbon age of $>34,000$ years B.P.

\section{INTRODUCTION}

In May 1967, an alert heavy-equipment operator, John Henson, unearthed bones of a fossil peccary while removing thick silt overburden from gravel in a pit about 1.5 miles $(2.5 \mathrm{~km})$ southwest of Hickman, Ky., along the Chickasaw Bluffs of the Mississippi River (fig. 1; Morgan, 1967). Mr. Henson immediately informed Richard W. White, M.D., owner of the pit. The following day Warren I. Finch, who was mapping the geology of the Hickman $71 / 2$-minute quadrangle, visited Dr. White to obtain permission for a field party to visit his properties, and Dr. White told Finch of the discovery. Dr. White unhesitatingly gave the U.S. Geological Survey permission to remove the bones. Excavation took about 5 days and disclosed a total of five peccaries. It was done under the direction of John D. Sims and Finch with the assistance of Roger Swanson, Don Russell, and Fred Wreck of the U.S. Geological Survey and of Robert Langford, Dr. White's nephew. Owing to the fragility of the bones, they were trucked by Finch and Sims to the U.S. National Museum, Washington, D.C., where under the direction of Frank C. Whitmore, Jr., they were cleaned for study and display. In the resulting study, presented here, the geologic portion is by Finch, the report on the peccaries is by Whitmore, and the portion on silt petrology is by Sims. All three authors collaborated in the interpretation of the data.

Original measurements were made in both the English and the metric systems; where possible, equivalent metric values and scales are shown.

\section{ACKNOWLEDGMENTS}

We thank and commend Mr. John Henson, excavator, of Columbus, $\mathrm{Ky}$., for his alertness in noticing the bones and in stopping his excavation to save them from destruction. We are grateful to Dr. Richard W. White for allowing us to excavate on his property, which made possible the preservation of the skeletons. Our appreciation is extended to all those who helped excavate the bones, particularly.to Robert Langford, a student of archeology at Memphis State University, for his capable and spirited assistance in the excavation. The peccary skeletons were prepared for study and exhibition by Sigmund J. Sweda, Division of Vertebrate Paleontology, U.S. National Museum; Ralph E. Eshelman, U.S. Geological Survey; and Susan H. Whitmore. Photographs of the skeletons shown in figures 9 through 13 are by Robert H. McKinney and Haruo E. Mochizuki, U.S. Geological Survey. John E. Guilday, Carnegie Museum, made helpful suggestions, as did Clayton E. Ray, U.S. National Museum, who reviewed the paleontological portion of the manuscript. We thank Craig C. Black of the Carnegie Museum and Mrs. Elizabeth Dalve of the University of Cincinnati for permission 
to study specimens at their institutions, ${ }^{1}$ and we thank G. Edward Lewis, U.S. Geological Survey, for furnishing measurements and data on the group of peccaries he collected in Denver, as well as for helpful discussion.

\section{GEOLOGIC SETTING}

The fossil peccary locality is near the axis of the northern part of the Mississippi embayment. The oldest rocks that crop out in the vicinity of the fossil locality are silt and clay of the Jackson Formation of late Eocene age. The Jackson is unconformably overlain at most places by continental gravel deposits of Pliocene (?) and Pleistocene age. Along the bluffs in the Hickman quadrangle, these gravel deposits range in thickness from 5 feet to more than 40 feet $(1.5-12 \mathrm{~m})$, and at the peccary site they average about 20 feet $(6 \mathrm{~m})$. A few miles east of the bluffs in the quadrangle, the gravel deposits are locally absent (Finch, 1971). The gravel deposits, and locally the Jackson Formation, are overlain by one or more blankets of predominantly eolian silt, whose combined thickness in the quadrangle ranges from 45 feet to 80 feet $(13.5-24 \mathrm{~m})$. The relations of the various geologic units at the fossil locality are shown in the section in figure 2.

\section{SILT STRATIGRAPHY}

In the area of the fossil locality, the silt can be divided into a lower unit, the Roxana Silt, and an upper unit, the Peoria Loess. The Roxana Silt is characteristically chocolate brown, noncalcareous, and unfossiliferous and in many places forms a fairly sharp contact with the overlying Peoria, which is commonly moderate-yellowish-brown calcareous fossiliferous silt. At the peccary site and at gravel pits 1,000 feet $(305 \mathrm{~m})$ to the north and about 1 mile $(1.5 \mathrm{~km})$ to the southwest (fig. 1), however, the Roxana is generally various shades of brown, but locally is gray, and is variably calcareous and fossiliferous. At these localities, the contact between the Roxana and Peoria is difficult to determine.

In the Hickman quadrangle, the Roxana is exposed only along and near the Chickasaw Bluffs (fig. 1), where it ranges in thickness from 0 to 15 feet $(0-4.6 \mathrm{~m})$. It either is indistinguishable from the Peoria or, as is more likely, is absent from the east half of the quadrangle. The Peoria is exposed throughout the upland area and ranges in thickness from 0 to 65 feet $(0-20 \mathrm{~m})$. Its thickness is greatest along the bluffs and thins to 25 feet $(7.6 \mathrm{~m})$ or less

\footnotetext{
${ }^{1}$ After Whitmore made his measurements of the Carnegie Museum specimen, the specimen was transferred to the National Museum of Canada, Ottawa. We are grateful to C. R. Harington of the National Museum for providing three additional measurements.
}

at the eastern boundary. The maximum combined thickness of the Roxana and Peoria in western Kentucky is 82 feet $(25 \mathrm{~m})$ in the Bondurant quadrangle, about 2 miles $(3.2 \mathrm{~km})$ south of the peccary site; at the peccary site the combined thickness is about 70 feet $(21 \mathrm{~m})$.

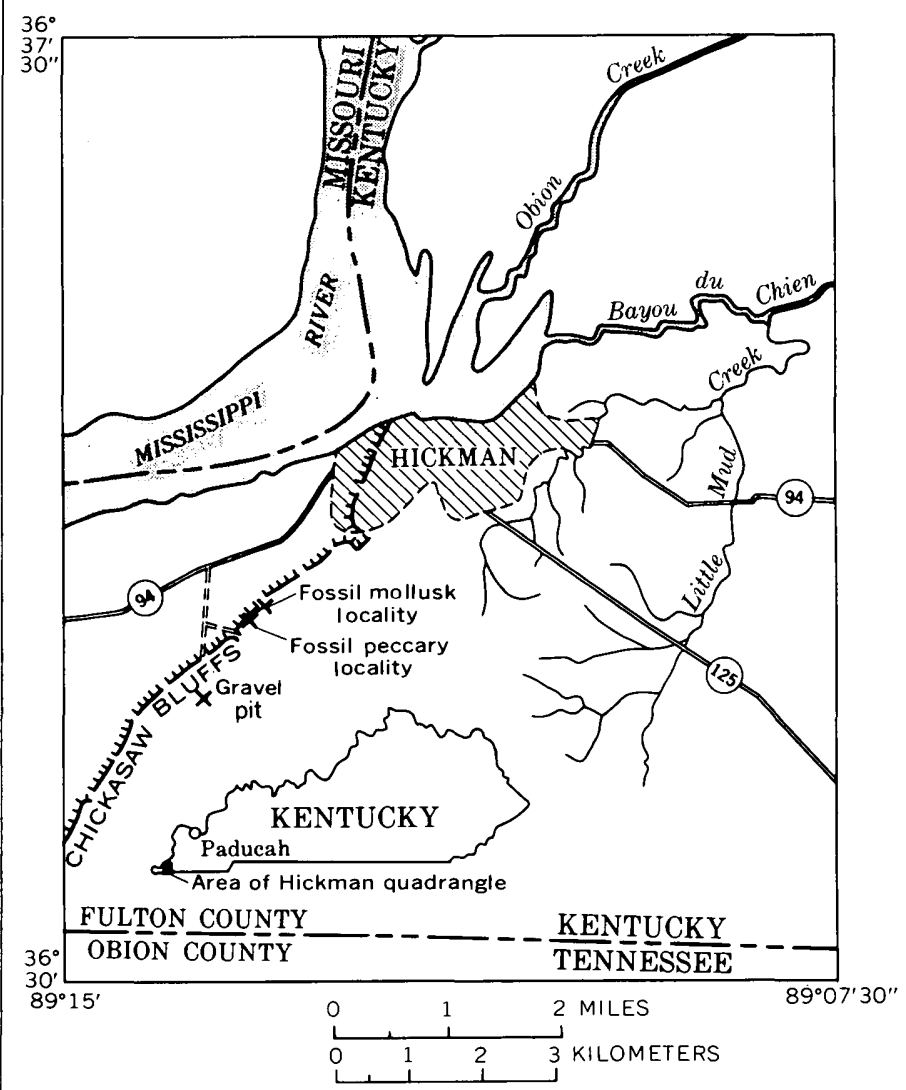

Figure 1. - Map of the Hickman $7 \frac{1}{2}$-minute quadrangle, showing the fossil peccary locality in western Kentucky.

A measured section of 66 feet $(20.1 \mathrm{~m})$ of silt at the peccary site follows. The calcareous character of the unit, determined with dilute hydrochloric acid, begins each description for emphasis. Color names and their numerical designations were determined by use of National Research Council's rock-color chart (Goddard and others, 1948).

Peoria Loess (upper $4 \pm \mathrm{ft}$ excavated) :

Feet Meters

8. Noncalcareous silt, light-yellowish-brown $(10 Y R 6 / 4)$, clayey, friable, unstratified, nonfossiliferous; A and B soil horizons not present owing to excavation.............. 17

7. Calcareous silt, very pale brown $(10 Y R$ $7 / 3$ ), slightly clayey, micaceous; abundant dark minerals; fossiliferous, most fossils occur singly (fossil mollusk locality $1,000 \mathrm{ft}(305 \mathrm{~m})$ north contains Deroceras laeve (Müller), Discus cronkhitei (Newcomb), Punctum minutissi- 
Peoria Loess-Continued mum (Lea), Succinea grosvenori gelida (Baker), Vertigo gouldii (Binney), Hendersonia occulta Say, and other terrestrial gastropods according to Browne and Bruder (1963)); nonstratified....... 32

6. Calcareous silt, pale-yellowish-gray (5Y $7 / 2$ ), clayey; abundant dark minerals, micaceous; contains large Gastropoda Allogona cf. A. profunda and Anguispiva cf. $A$. kochi in lower part; fairly compact; nonstratified.

Total measured thickness of Peoria Loess..

Roxana Silt:

5. Mostly noncalcareous silt but some spots weakly calcareous, light-yellowish-brown $(10 Y R 6 / 4)$ to medium-yellowish-brown $(10 Y R 5 / 2)$, clayey; abundant dark minerals; abundant root casts where calcareous; micaceous; nonfossiliferous; compact; nonstratified.

4. Noncalcareous and subordinately calcareous silt, grayish-orange $(10 Y R \quad 7 / 4)$ to moderate-yellowish-brown (10YR $5 / 4)$, slightly clayey; abundant dark minerals; contains carbonized wood fragments as much as $3 \mathrm{~cm}$ long and, where calcareous, abundant carbonate root casts ; compact; nonstratified..................

3. Mixed noncalcareous and calcareous silt, moderate-yellowish-brown (10YR 5/4); Liesegang-like bands of grayish-orange (10YR 7/4) and dark-yellowish-orange (10YR 6/6), sparse clay, abundant dark minerals; pebbly; contains smooth-surfaced spheroidal nodules of calcium carbonate called loess kindchen $5-20 \mathrm{~mm}$ in diameter; contains fossil peccaries Platygonus compressus Le Conte and gastropods Anguispira kochi that occur singly but more commonly in clusters 5-8 $\mathrm{m}$ in diameter; pebbles in peccary zone consist of brown well-rounded to angular chert from granule size to $6 \mathrm{~cm}$ long, yellowish-white quartz as much as $15 \mathrm{~mm}$ across, yellow and red quartzite as much as $2 \mathrm{~cm}$ across, and one silicified crinoid stem section; compact; nonstratified.

2. Mixed noncalcareous and subordinately calcareous silt, light-brown $(5 Y R$ 6/4) to moderate-yellowish-brown (10YR $5 / 4)$, slightly clayey, micaceous; abundant dark minerals; sparse very fine quartz grains in lower $1 \mathrm{ft}(0.3 \mathrm{~m})$; some carbonate root casts; very sparse brown chert pebbles; locally contains sparse to abundant carbonized wood fragments 1-4 mm across in upper $1 \mathrm{ft}$ $(0.3 \mathrm{~m})$ of dark-yellowish-brown $(10 Y R$ 4/2) silt; a few clusters of gastropod Anguispira kochi; compact; nonstratified.

Roxana Silt-Continued

1. Noncalcareous clayey silt, very pale brown $(10 Y R 7 / 2)$ to moderate-yellowish-brown $(10 Y R$ 5/4); sparse coarse to very coarse quartz grains, very sparse brown chert pebbles; compact, nonstratified; intergrades with underlying gravel........

Total thickness of Roxana Silt........... $\overline{11} \quad \overline{3.3}$

Total measured thickness of Roxana Silt and Peoria Loess. \begin{tabular}{ll}
66 & 20.1 \\
\hline
\end{tabular} Continental deposits:

Gravel, moderate-brown; pebbles, chiefly brown chert, as much as $5 \mathrm{~cm}$ across; clayey sand matrix...................................... $1+\quad .3+$

Figure 2. - Section showing the stratigraphic setting of fossil peccaries in Roxana Silt at White's gravel pit near Hickman, Ky. Vertical exaggeration $\times 4$. Altitude is in feet above mean sea level.

The silt at the peccary site is of rather uniform texture and is unstratified. Division of the silt into stratigraphic units is based mainly on color and on the presence or absence of calcareous zones. Three distinct but uneven and gradational color changes occur at the tops of units 3,5 , and 7 , and one less 
distinct occurs at the top of unit 6 . The silt is calcareous, except for unit 8 and for parts of units 1 through 5. At the outcrop the most noticeable break comes at the top of unit 5 , about 11 feet $(3.4 \mathrm{~m})$ above the base. This break marks the highest noncalcareous silt and also separates moderate-brownish shades below from pale-grayish and pale-brownish shades above. The lower five units are designated here as the Roxana Silt; those above, as the Peoria Loess. Units 7 and 8 are typical Peoria, but unit 6 seems to be a gradational zone between the Peoria and Roxana. The uppermost part of the Peoria, as represented by unit 8 , is everywhere leached of its carbonate content. On the basis of a study of fossil Mollusca from a locality about 1,000 feet $(305 \mathrm{~m})$ to the north (fig. 1), Ruth G. Browne (written commun., 1967) placed the contact between "probable Farmdale" (Roxana as used here) and "typical Peoria" at about 15 feet $(4.6 \mathrm{~m})$ above the base of the silt section, which is just above the highest occurrence of the large Gastropoda Allogona profunda and Anguispira kochi. This contact corresponds with the highest occurrence of large gastropods, probably the same species, in unit 6 at the peccary site.

The Roxana Silt is mostly of eolian origin, but the lower 1-4 feet $(0.3-1.2 \mathrm{~m})$ is at least partly alluvial. Scattered quartz and chert grains and pebbles in this lower part become more abundant toward the contact with the underlying gravel. A few crudely imbricate layers of whole and broken snail shells in this lower part indicate stream action. The lower 1-4 feet $(0.3-1.2 \mathrm{~m})$ of the Roxana represents a transition between alluvial and eolian deposition, which was accompanied by soil formation. Such a transitional zone, though common between gravel and loess in this region, is generally better developed and is characterized by red color and very abundant sand and pebbles. At the peccary site the upper limit of the transition zone seems to be an indistinct, uneven surface beneath which the silt is more compact than the silt above.

Liesegang-like bands of limonitic coloration occur in the upper part of the transition zone; in some places these bands extend upward several feet into the overlying silt, and in others they extend downward nearly to the base of the Roxana. Most of the bands concentrically enclose silt of normal color; these centers may contain fossils. The fossil peccaries appear to lie on the upper surface of the transition zone and are enclosed by Liesegang-like bands. The banding is thought to have been produced by ground water carrying organic by-products of reduction away from the peccaries and other organisms. Occurrence of similar color bands was noted also at a gravel pit about 1 mile $(1.5 \mathrm{~m})$ southwest of Dr. White's pit (fig. 1). The association of the bones with color bands suggests that the areas in and around, and possibly between, these pits may be favorable sites for finding more vertebrate fossils.

The name Roxana Silt is used here for the lower formation in preference to Farmdale Loess as previously used by Leighton and Willman $(1949,1950)$ in the Hickman area. A radiocarbon age of $>34,000$ years B.P. for the unit suggests that the unit is the Roxana Silt (Frye and Willman, 1960) and that it is correlative to part of the Altonian Substage of the Wisconsinan Stage, as used nearby in Illinois by Frye and Willman (1960). They restrict the term Farmdale to the organic-rich radiocarbon-dated silt and peat at and near the type locality in Illinois, and they define the Roxana Silt as the loessal and alluvial silt lying beneath the Farmdale (fig. 3). Leighton (1960) redefined the original Farmdale and proposed "a new name, Farm Creek, for the deposits of the original Farmdale type section in order to retain the name Farmdale for the glacial substage represented by loess deposition" (Frye and others, 1968, p. 15-16). Farmdale Silt as used by Frye and Willman (1960) is not present at the peccary locality.

Loveland Silt of Illinoian age was not found in the Hickman area, but Leighton and Willman (1949, p. 52,$55 ; 1950$, p. 614) reported Loveland Loess beneath Farmdale Loess (Roxana Silt as used here) in the Mississippi River bluffs at localities that are 15 miles $(24 \mathrm{~km})$ to the north and 15 miles to the southwest of Hickman.

The Sangamon soil zone in the upland areas of the northern Mississippi embayment commonly occurs beneath either Peoria Loess or Roxana Silt, but it occurs only beneath Roxana where both the Peoria and the Roxana are present (fig. 3). It is developed only on Loveland Silt. Most of the zone is 3-6 feet $(0.9-1.8 \mathrm{~m})$ thick. It has not been found in the Hickman area.

\section{SILT PETROLOGY}

Mineralogic and size anayses were made of the seemingly uniform silt of the Roxana and the lower part of the Peoria to investigate the validity of the field-determined contact between the two formations and to search for fossil soils developed at this contact as well as within the Roxana, especially at the peccary horizon. Fabric studies were made of oriented silt samples to test the generally accepted eolian origin of the silt. Paleowind directions indicated by the fabric study fit well the eastward thinning of the silt in the Hickman area and provide useful data on the paleoecology of the peccaries. 


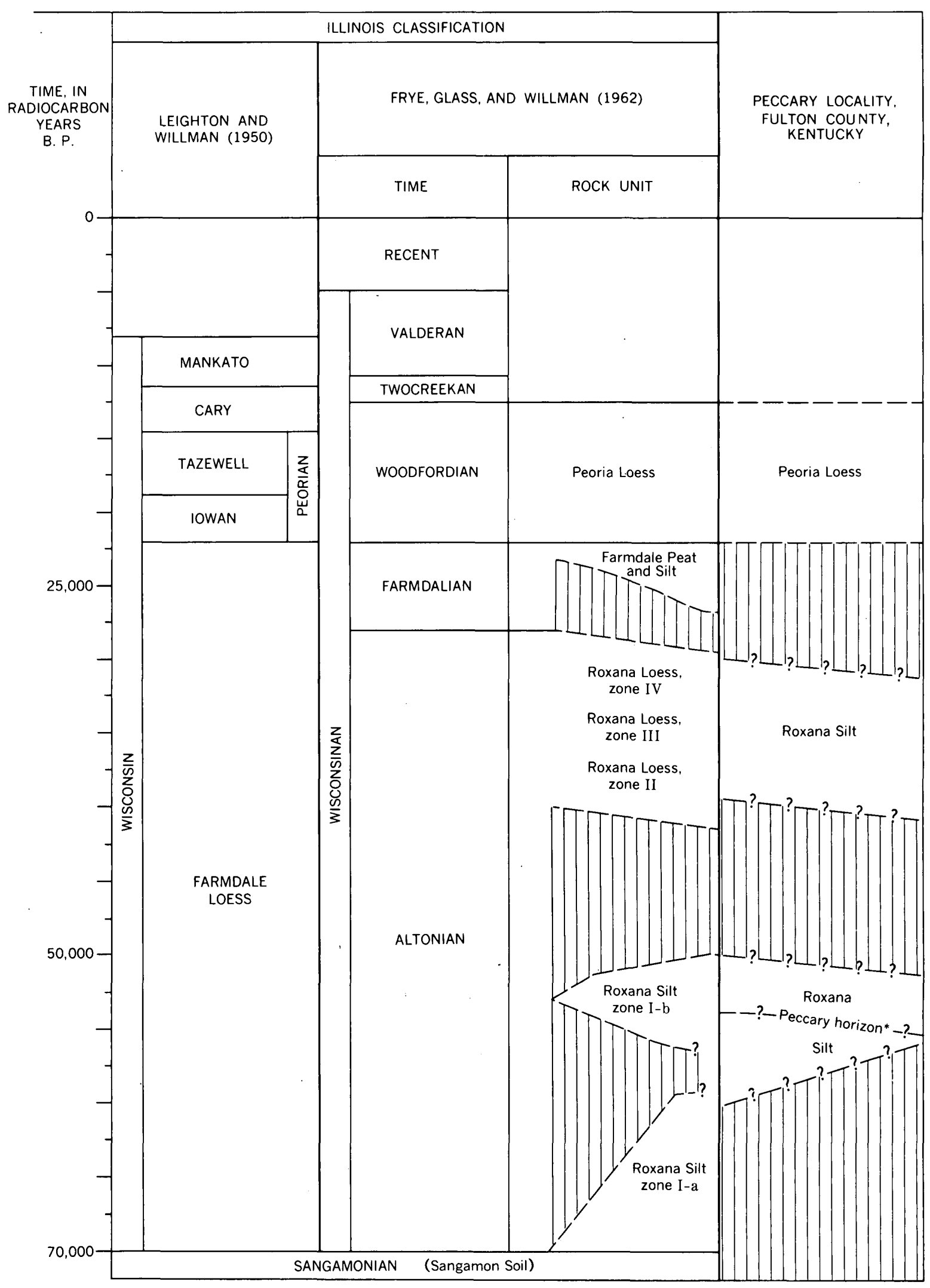

Figure 3. - Correlation of silt units at the peccary locality with the classification of the Wisconsinan in Illinois (modified from Frye and Willman, 1963). *Approximate position of peccary horizon plotted according to probable stratigraphic position rather than radiocarbon age of $>34,000$ years B.P. 

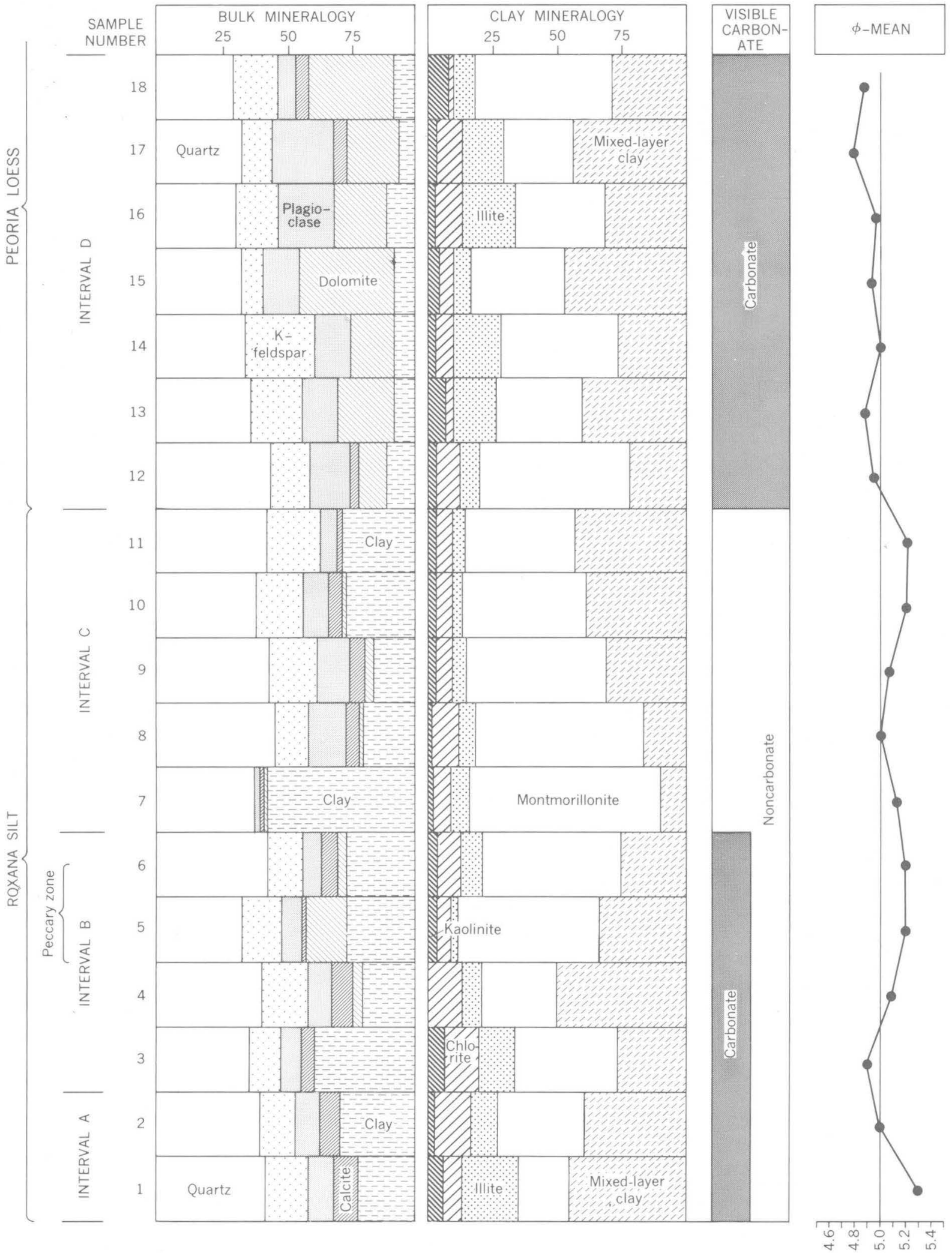

Figure 4. - X-ray mineralogy, microscopically visible carbonate content, and $\phi$-mean of samples 1-18. Methods used to determine clay mineralogy are described by Schultz (1964); precision of determinations is generally within 10 percent. 
Samples of Roxana Silt and Peoria Loess were taken near the exposed bones of the peccaries from an 18 -foot $(5.5 \mathrm{~m})$ section extending upward from the top of the continental gravel deposits. Each sample consisted of an oriented block, measuring about 6 by 6 by 3 inches ( 15 by 15 by $8 \mathrm{~cm}$ ), from the midpart of each 1-foot $(0.3 \mathrm{~m})$ segment above the top of the gravel. The largest face of each block was parallel to the pit wall. Before removing each block from the pit wall, the azimuthal orientation of the face and a vertical were scribed on the block. Thin sections were cut parallel to the horizontal plane from each oriented sample. Bulk mineralogical, claymineral, and size-distribution determinations were made from material trimmed from each sample block.

\section{MINERALOGY AND SIZE ANALYSES}

Quartz, microcline, plagioclase, calcite, dolomite, and undifferentiated clay minerals were identified in thin sections. On the basis of mineralogy and texture of the silts in thin sections, the sampled section is seen to consist of four intervals (fig. 4) : interval A, lowermost 2 feet $(0.6 \mathrm{~m})$ (samples 1 and 2$)$, sandy clayey silt with carbonate root casts; interval $\mathrm{B}, 4$ feet $(1.3 \mathrm{~m})$ (samples $3-6)$, feidspathic clayey silt, containing carbonate root casts in lower foot and disseminated calcite grains in upper 3 feet $(0.9 \mathrm{~m})$; interval C, 5 feet $(1.5 \mathrm{~m}$ ) (samples 7-11), noncalcareous dominantly nonfeldspathic clayey silt; and interval D, 7 feet $(2.1 \mathrm{~m}$ ) (samples $12-18)$, very calcareous silt with disseminated dolomite and calcite grains. Intervals $\mathrm{A}, \mathrm{B}$, and $\mathrm{C}$ correspond to the Roxana Silt, and interval D corresponds to the lower part of the Peoria Loess, as determined in the field. The peccary skeletons were found within $1 / 2-2$ feet $(15-60 \mathrm{~cm})$ of the top interval B.

Bulk mineralogy of unoriented samples and clay mineralogy of the $<10 \mu$ (microns) oriented fractions on settle slides determined by X-ray analysis (Schultz, 1964) are shown in figure 4 . The $<10 \mu$ fractions are chiefly clay minerals. These fractions contain montmorillonite and mixed-layer clays and minor amounts of illite, chlorite, and kaolinite. Mixedlayer clay minerals having possible montmorillonitevermiculite interlayering (L. G. Schultz, oral commun., 1968) are abundant in all samples. Claymineral proportions are given as percentages of the bulk sample and as percentages of the total clay-mineral fraction (fig. 4).

Mean and standard deviations for clay-mineral contents of the clay mineral fraction of the samples are shown in figure 5. Values for montmorillonite and mixed-layer clay minerals combined for all samples average 77.8 percent. The content of mixed- layer clay minerals, which probably contain montmorillonite interlayers, averages 33.2 percent. Chlorite percentages are uniformly low and are generally near the limits of detection (Schultz, 1964, p. C13-C14). Kaolinite contents are low and do not exceed 10 percent. Illite averages about 10 percent in the 18 samples. The standard deviations $(\sigma)$ for kaolinite, chlorite, and illite are $\leqslant 6.0$ percent, whereas for montmorillonite and mixed-layer clay they are $\geqslant 6.0$. The magnitude of $\sigma$ of the clay-mineral contents increases in the order kaolinite $<$ chlorite $<$ illite $<$ montmorillonite $\approx$ mixed-layer clay minerals. Interval D (Peoria Loess) averages more kaolinite, illite, and mixed-layer clay and less chlorite and montmorillonite than intervals $B$ and $C$ (Roxana Silt, above the transition zone).

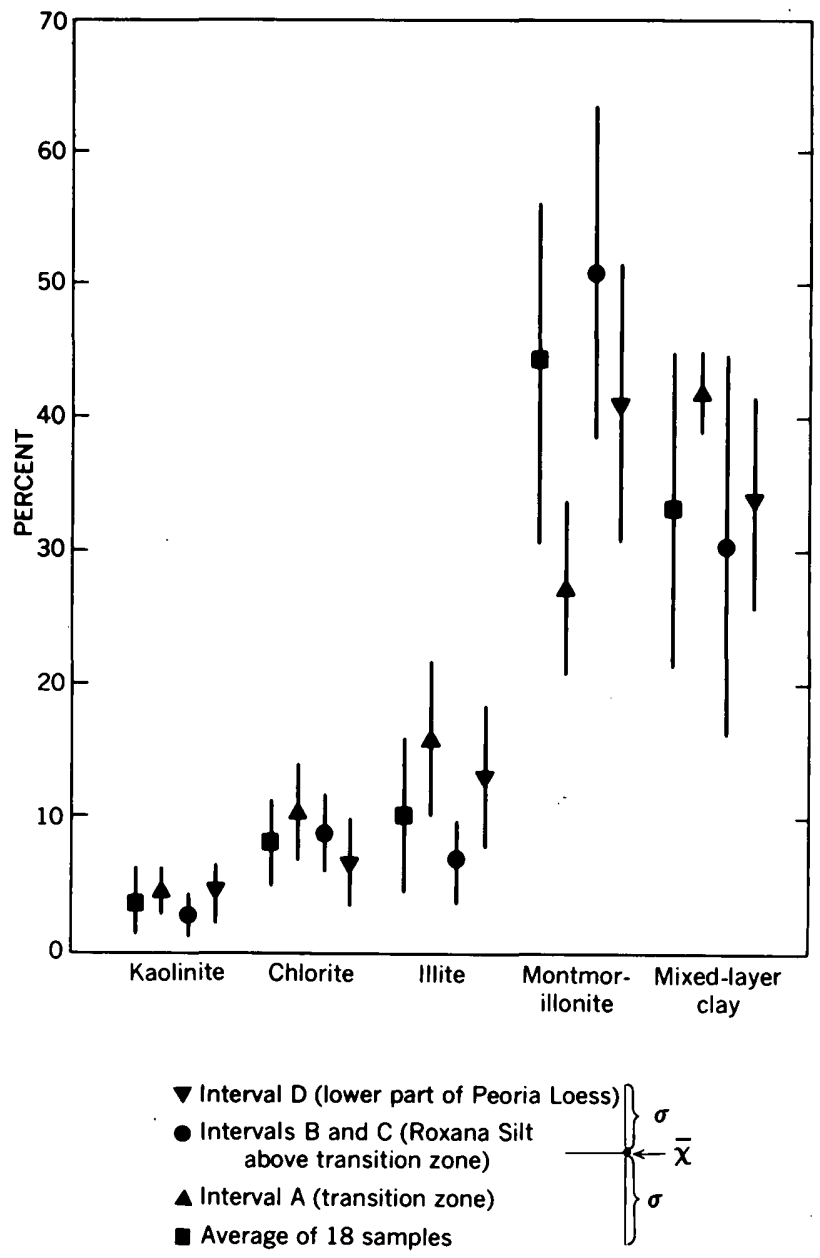

Figure 5. - Mean $(\bar{\chi})$ and standard deviation $(\sigma)$ of clay-mineral content of silt from peccary locality.

Bulk mineralogic determination by X-ray diffraction shows that interval $D$ (Peoria Loess) has a mean carbonate content of 24 percent (fig. 4). Interval C (upper part, Roxana Silt) contains no visible 
carbonate minerals as seen in thin sections, but it contains as much as 9 percent as determined by $\mathrm{X}$-ray diffraction. Sample 11 shows an increase in total clay and a decrease in feldspar and dolomite over sample 12. Sample 7 shows a near absence of feldspars and carbonates and a high clay content. This clay contains more than 75 percent montmorillonite, the highest proportion of the mineral in any of the 18 samples. The average total carbonate content of interval $\mathrm{D}$ is 24 percent, whereas the average of intervals $\mathrm{B}$ and $\mathrm{C}$ is 7 percent. Thin-section examination shows that the carbonate grains in interval $B$ have two habits: some grains are subangular to subrounded and appear to be detrital; the others have intricate grain boundaries that interlock with grains of quartz, feldspar, and clay clasts, and they appear to be recrystallized or authigenic. Dolomite is the dominant carbonate mineral in interval $\mathrm{D}(\mathrm{Pe}-$ oria) and a minor constituent in intervals $\mathrm{A}, \mathrm{B}$, and $C$ (Roxana). Calcite is rare or absent in interval $D$ (Peoria) but is present in amounts greater than those of dolomite in intervals A, B, and C (Roxana), except in sample 5. Frye, Glass, and Willman (1962, p. 13) stated that calcite is more common than dolomite in the Roxana south of the Missouri River, whereas dolomite is the dominant carbonate mineral in the Peoria in Illinois. These differences are explained by the fact that the older western tills, which were sources of detritus for the Roxana, are high in calcite, whereas the younger tills to the east in the Lake Michigan lobe, which were sources of detritus for the Peoria, are high in dolomite.

Size analyses of the silt were made by means of a Coulter Counter (electronic zone-sensing particlesize analyzer). The $\geqslant 5 \mu$ fraction was analyzed at intervals of $0.5 \phi$. Phi-means range from 4.8 to 5.3 units $(36 \mu-25 \mu)$ and are plotted in figure 4 . These data show little variability though the $\phi$-mean (coarsening) in samples stratigraphically above sample 11 (fig. 4) in general slightly decreases. Sample 11 probably represents the contact zone between the Roxana Silt and the Peoria Loess. Phi-skewness values are also relatively constant throughout the sampled interval. Visual inspection of the plot of $\phi$-means $\left(\mathbf{M}_{\phi}\right)$ in figure 4 shows $\mathbf{M}_{\phi}$ to be $<5.0$ for six samples from the Peoria and shows $\mathrm{M}_{\phi}$ to be $>5.0$ for eight samples and $<5.0$ for one sample from the Roxana (excluding samples where $\mathrm{M}_{\phi}=5.0$ ). The value $\mathrm{M}_{\phi}=5.0$ serves as a discriminant between the coarser grained silt of the Peoria above and the finer grained silt of the Roxana below at this locality. Analysis of the $\phi$-means by the Fisher exact probability test (Siegel, 1956) at the $>99.8$-percent confidence level results in the rejec- tion of the hypothesis that $\phi$-means from Peoria and Roxana belong to a single population.

\section{INTERPRETATION}

The mineralogic and size data may be interpreted two ways with respect to stratigraphy and possible fossil soils. The preferred interpretation is the designation of samples 1 and 2 (interval A) as pre-Wisconsinan paleosol and mixed loess and bedrock materials formed at the onset of loess deposition on the pre-Wisconsinan land surface; samples 3-11 (intervals B and C), as Roxana Silt (for purposes of mapping and general stratigraphic discussion samples 1 and 2 are included in the Roxana) ; and samples 1218 (interval D), as the lower part of the Peoria Loess. If samples 3-11 represent Roxana, then samples 7 and 8 are interpreted as soil formed on the Roxana I-b of Frye and Willman (1963) and samples 9-11 are interpreted as part or all of Roxana zones II, III, and IV of Frye and Willman (1963) (fig. 3). Radiocarbon dating of Mollusca associated with peccary bones indicate an Altonian age for the fossil horizon, which is placed in Roxana zone I-b (fig. 3). The Farmdalian Substage (Frye and Willman, 1960) may be represented by a period of leaching that modified the Roxana to an apparent depth of 5 feet $(1.5 \mathrm{~m})$ (visible-carbonate column, fig. 4). Such a depth of modification is supported by the leaching that has accompanied Holocene soil formation on the Peoria to depths as great as 12 feet $(3.7 \mathrm{~m})$. Similar leaching has been proposed by Frye, Glass, and Willman (1962) to partially explain differences in carbonate mineral assemblages in the Roxana and Peoria.

The second interpretation is the definition of three stratigraphic units that have intervening fossil soils. Samples 1 and 2 are again designated as pre-Wisconsinan paleosol and mixed loess and bedrock materials. The Roxana (Frye and Willman, 1960) may be represented by samples $3-8$, whose paleosol is represented by samples 7 and 8 . An equivalent of the Farmdale Silt (Frye and Willman, 1960) may be represented by samples 9-11, whose paleosol is represented by sample 11. The lower part of the Peoria Loess is then represented by samples $12-18$, interval D. This scheme allots a rock-stratigraphic unit to each time-stratigraphic subdivision of the Wisconsinan Stage (Frye and others, 1962). Frye and Willman's (1960) restriction of their Farmdale to the area near the type locality, however, probably rules out this interpretation.

\section{SILT FABRIC AND PALEOWIND DIRECTIONS}

The silt fabric was studied to determine the paleowind directions for the Roxana Silt, the peccary 

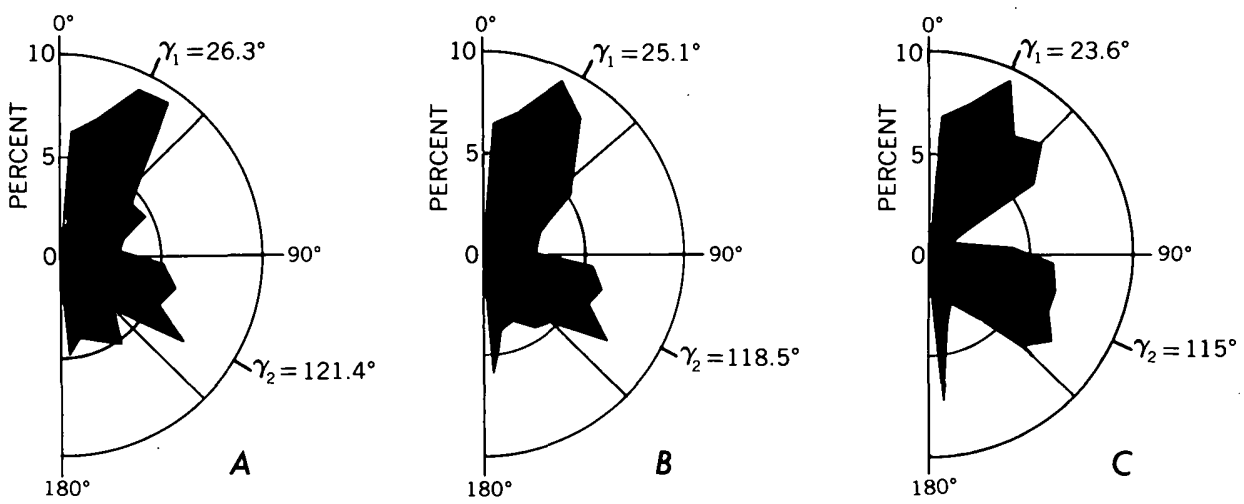

FiguRe 6. - Silt-fabric rose diagrams. Data for the Roxana Silt and Peoria Loess were shown to be significantly bimodal at $>0.99$ significance level by the $\chi^{2}$ text. (See footnote on page 10.) $\gamma$, vector mean direction; $\theta$, dispersion factor; $\alpha$, contribution of dominant mode. $A$, Roxana Silt, samples $3-11,870$ observations. Bimodal model values : $\alpha=61.3$ percent, $\theta_{1}=1.26, \theta_{2}=1.56$. $B$, Roxana Silt and Peoria Loess, samples $3-18,1,547$ observations. Bimodal model values: $\alpha=61.7$ percent, $\theta_{1}=1.5$, $\theta_{2}=1.7$. $C$, Peoria Loess (basal $7 \mathrm{ft}$ ), samples 12-18, 677 observations. Bimodal model values: $\alpha=62.2$ percent, $\theta_{1}=1.57, \theta_{2}=1.91$.

zone, and the lower part of the Peoria Loess. The azimuths of the apparent longest physical (not optical) axes of about 100 elongated quartz grains were measured in each of 16 horizontally oriented thin sections from samples 3-18. Quartz grains were chosen for two reasons. First, silt-sized quartz is the dominant mineral in the sections, and second, quartz lacks cleavage that might give rise to orientations based chiefly on cleavage as would calcite, dolomite, and feldspar. The effect of imbrication on the apparent grain shape was tested in one vertically oriented thin section from sample 13. The mean imbrication in this section is $8^{\circ} \mathrm{E}$. This value is within the range of imbrication data reported by Matalucci, Shelton, and Abdel-Hady (1969) for loess at Vicksburg, Miss., and indicates that imbrication has only a slight effect on the apparent grain shape. The quartz grains are assumed to be oriented parallel to paleowind-current directions (Potter and Pettijohn, 1963, p. 54). The resultant paleowind directions are compared with the dominant present-day wind directions recorded by the U.S. Weather Bureau for Barkley Field, Paducah, Ky., about 40 miles $(65 \mathrm{~km})$ northeast of Hickman.

The azimuths of quartz grains measured for samples from the Roxana and Peoria, separately and combined, are plotted in $10^{\circ}$ classes and are expressed as percentages of total observations in the eastern semicircles of silt-fabric rose diagrams in figure 6. A similar diagram for the peccary zone is presented in figure 8. Diagrams constructed for each of the 16 individual samples are very similar to those shown in figures 6 and 8 . In figure 7, the present-day wind data are plotted in sixteen $221 \%^{\circ}$ classes as the stippled area on the full-circle wind rose and are replotted as the black area on the eastern semicircle to conform to the convention used in the plots in figures 6 and 8.

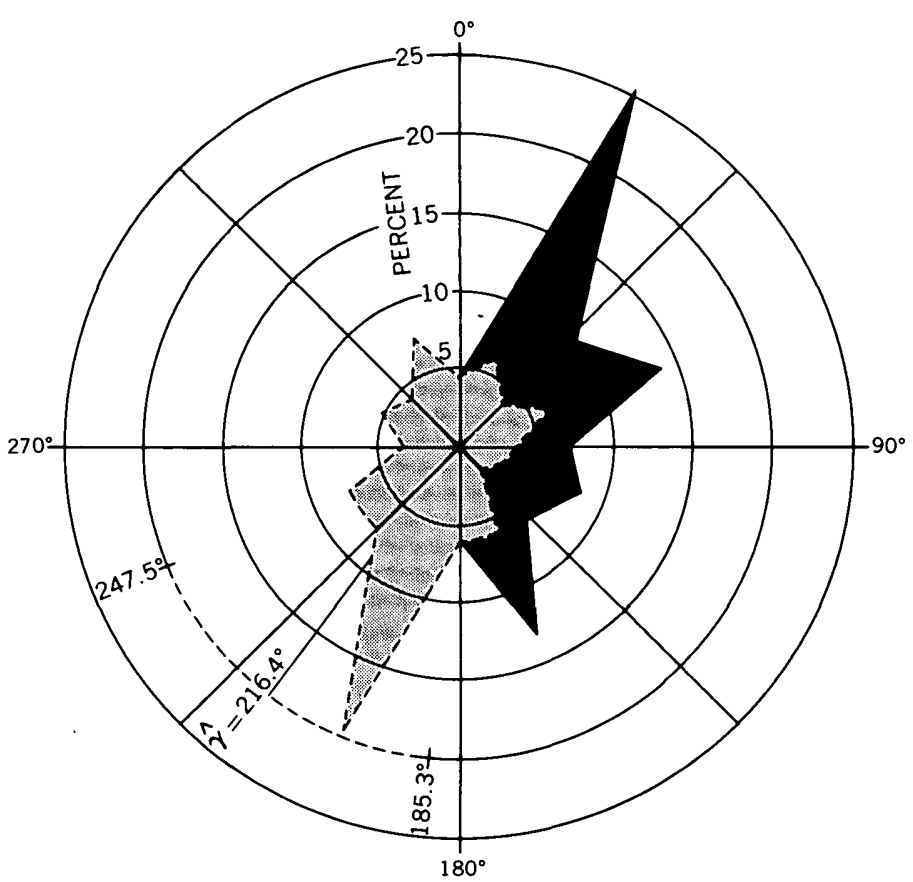

Figure 7. - Full-circle wind rose (stippled area) based on about 40,000 azimuthal readings of directions from which wind blew (calm readings not included) at Barkley Field, Paducah, Ky., January 1950-December 1954, taken by U.S. Weather Bureau; semicircle wind rose (black area) of strike directions of same wind data. Vector mean direction $(\hat{\gamma})$ and confidence interval (dashed arc span) at $>0.95$ significance level. 


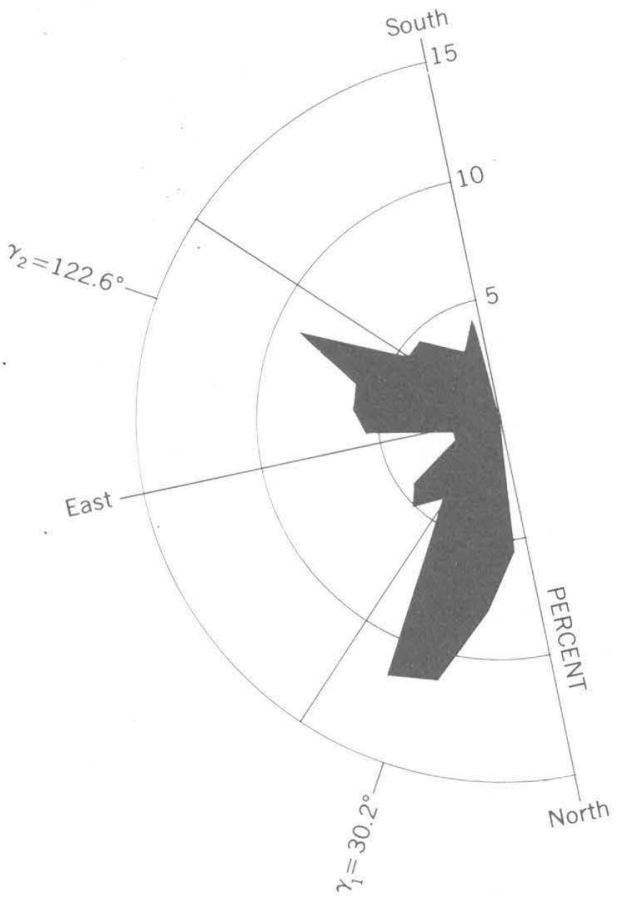

FIGURE 8. - Silt-fabric rose diagram for samples 5 and 6 combined to give 200 measurements from peccary zone. (See footnote 2.) $\gamma$, vector mean; $\theta$, dispersion factor; $\alpha$, contribution of dominant mode. Bimodal model values: $\alpha=66.4$ percent, $\theta_{1}=-0.302$, $\theta_{2}=-0.066$. Diagram is oriented with respect to plan view.

Figure 9. - Plan view (upper) of five peccary skeletons, labeled 1-5 (grid is in 1-ft squares), and section (lower) showing relative position of blocks $B$, $\mathrm{A}, \mathrm{J}$, and $\mathrm{K}$. Altitude is in feet above mean sea level.
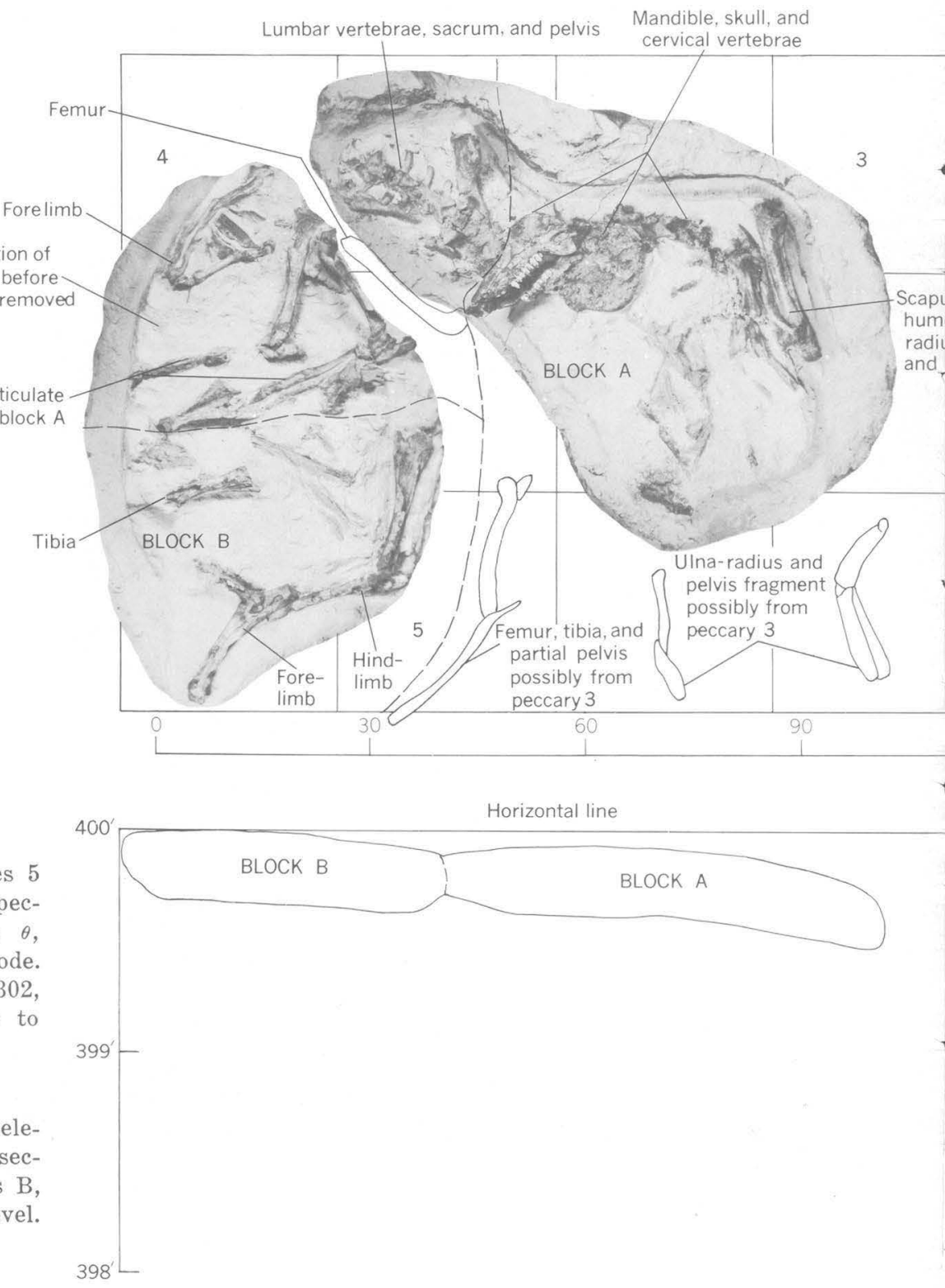

The silt-fabric rose diagrams in figures 6 and 8 and the semicircle wind rose in figure 7 are obviously bimodal and cannot be treated by statistics assuming a unimodal model (T. A. Jones, written commun., 1971). Various bimodal statistical parameters are shown for the silt-fabric rose diagrams in figures 6 and $8 .^{2}$ Tests by use of the bimodal model are not available for comparison of the statistical fit of the vector means $(\gamma)$, or implied paleowind directions, of the silt-fabric rose diagrams with the present-day wind directions.

The silt-fabric rose diagrams shown in figures 6 and 8 are strikingly similar to the semicircle wind rose for present-day winds shown in figure 7. Thus, if the long axes of quartz grains record wind-current directions, it is apparent that the wind directions during the time represented by the peccary zone were similar to the dominant southwestern and the northwestern winter-storm winds of the present time.

2The bimodal model is based on a circular normal distribution (Stephens, 1962,1964 ; Jones, 1967, 1968). In order to treat the semicircularly distributed silt-fabric data by use of a bimodal model, the azimuthal angles must be doubled, according to James and Jones $(1969$, p. 129). The distribution of these data with doubled angles is also bimodal, which indicates that the bimodal model is needed to calculate the statistical parameters for these populations. The parameters-vector means $\left(\gamma_{1}\right.$ and $\left.\gamma_{2}\right)$, dispersion factors $\left(\theta_{1}\right.$ and $\theta_{2}$ ), and percentage contribution $(\alpha)$ of the dominant mode -are calculated for this new distribution on the basis of the bimodal model of James and Jones (1969) and T. A. Jones (written commun., 1971). The data shown in figures 6 and 8 are significantly bimodal by the $x^{2}$ test at $>0.99$ significance and have means, dispersion factors, and percentage contributions consistent with the data and assumption of the statistics. 

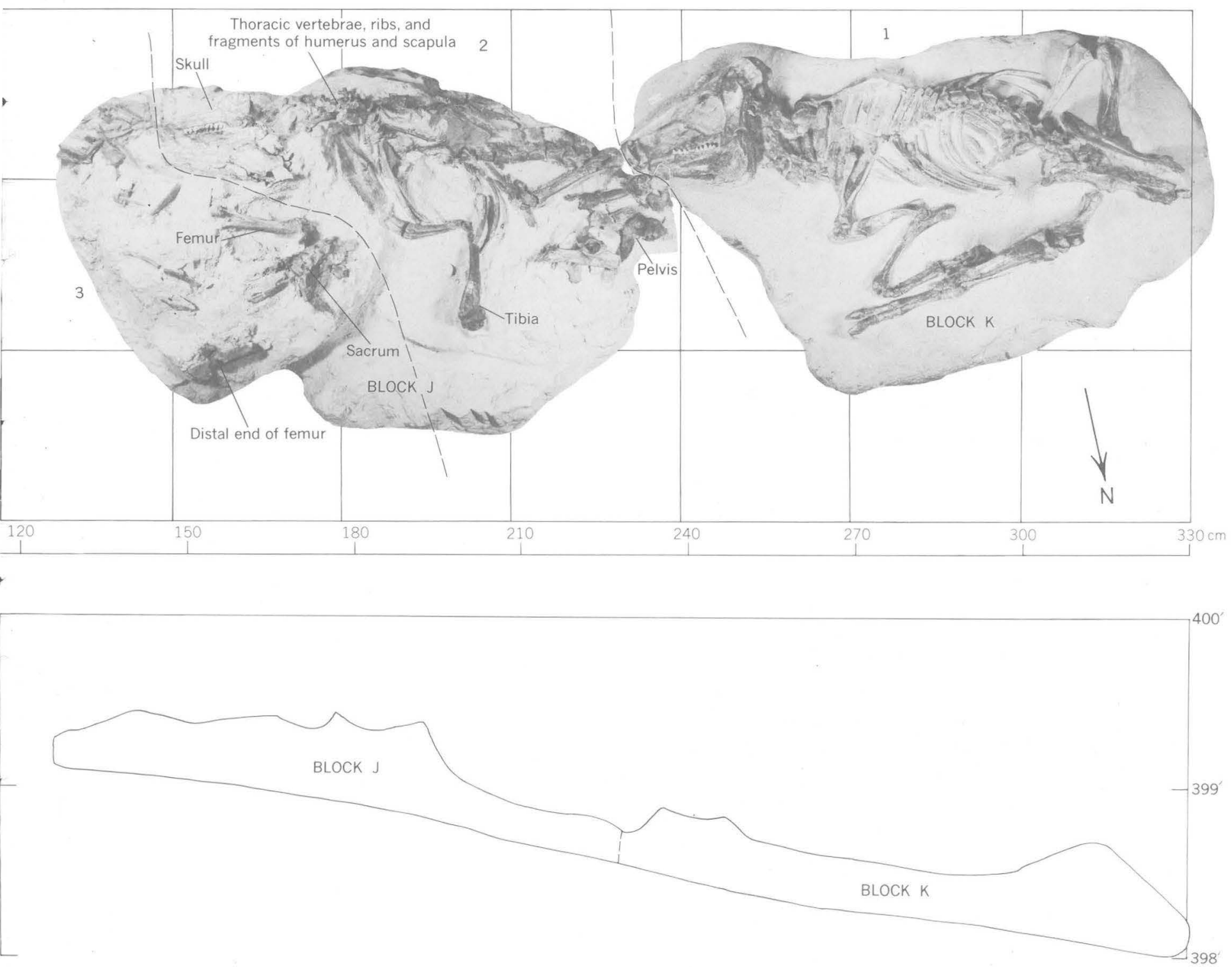

Smith (1942), in his study of loess (silt) in Illinois, found that silt is thickest along major rivers and thins rapidly away from them, as it does away from the Mississippi River in the Hickman area. $\mathrm{He}$ found that the rate of thinning is a linear function of the logarithm of the distance from the source of silt and that the depositional pattern of silt is also a function of variations in the major wind directions with respect to flood-plain configuration (Smith, 1942 , p. 162). Smith's study and a more comprehensive one of the whole western Kentucky region by J. D. Sims (written commun., 1970) suggest that the two major wind directions, southwesterly and northwesterly, caused the silt to pile up thickest along the bluffs near the Mississippi River.

\section{FOSSILS}

Peccaries are the only vertebrate fossils found at the Hickman site. The skeletons are the remains of a herd or family group of Platygonus compressus Le Conte 1848. Other such occurrences of this species have been reported by Klippart (1875), Leidy (1889), Williston (1894), Wagner (1903), Clarke (1916), Hoare, Coash, Innis, and Hole (1964), Lewis (1970), and Elizabeth Dalvé (written commun., 1969). Of these occurrences, only one appears to have been in loess: that reported from Goodland, Kans., by Williston. Although Williston stated that his peccary group was found in a loose sandy marl, Hay (1924, p. 158) was certain that the bones were buried in loess. Hay's opinion is corroborated by the 
map of Pleistocene eolian deposits of the United States (Natl. Research Council, 1952), which shows Goodland, Kans., in an area where 67-100 percent of the land is covered by loess $8-16$ feet $(2.4-4.9 \mathrm{~m})$ thick. The skeletons reported by Hoare, Coash, Innis, and Hole (1964) may have been buried in dune sand. Lewis (1970) reported the skeletons of at least five individuals found in eolian sand and silt in Denver. Besides these few discoveries of skeletons, there have, of course, been scattered surface finds of disarticulated bones and a remarkably large number of occurrences of peccary bones in caves. Hay in 1923 and 1924 summarized discoveries up to those dates, and subsequent reports have been made by many other authors.

Associated with the peccaries are fossil gastropods. At and within a foot or so of the stratigraphic level of the peccaries are widely scattered bits of carbonized plant matter, probably wood. The plant matter is fairly abundant in pockets and layers. In the calcareous silt, carbonate root casts are abundant. Near the peccaries and in a zone 3-6 feet $(0.9-1.8 \mathrm{~m})$ above the base of the Roxana are numerous white powdery, but well-preserved, calcareous fossil hackberry seeds.

\section{PLATYGONUS COMPRESSUS LE CONTE 1848}

The five fossil peccaries where found appeared to lie on a surface that marks the end of mixed alluvial and eolian silt deposition; they were covered by wholly eolian silt. The surface forms an irregular plane dipping from $0^{\circ}$ to $10^{\circ} \mathrm{NW}$. The five skeletons, all headed toward the east roughly parallel to one of the two vector mean directions shown in figure 8 , lay in a line trending approximately S. $80^{\circ} \mathrm{E}$. within an area about 3 feet $(1 \mathrm{~m})$ wide and 11 feet $(3 \mathrm{~m})$ long (fig. 9). The snout of skeleton 1 touched the rear of skeleton 2 ; the snout of 2 was about 1 foot $(0.3 \mathrm{~m})$ southeast of the sacrum of 3 ; the snout of 3 touched the rear of 4 ; the heads of 4 and 5 (destroyed before recovery) were probably within 1 foot $(0.3 \mathrm{~m})$ of each other and pointed in the same direction. The westernmost pair of skeletons ( 1 and 2) are best preserved (figs. 10, 11) ; they lay at a lower altitude and were apparently covered more deeply and quickly than the three skeletons clustered to the east of them. The disposition of the skeletons indicates that the peccaries were suddenly overcome and were very quickly buried by eolian dust. Skeletons 1 and 2 were undisturbed after death. This is undoubtedly true also of skeletons 3 and 4 , but their higher altitude may have resulted in damage and movement of some bones during bulldozer passes associated with the discovery. Also two bones which we associate with skeleton 3 were found 1 and 2 feet, respectively, north of the skeleton. One forelimb and one hindlimb of skeleton 5 were lying in a proper position relative to each other so that we conclude that they were not moved after the animal died. The other hindleg associated with this skeleton was found, still articulated, 1 foot $(0.3 \mathrm{~m})$ west of its mate. This is slightly out of position for a natural pose, and it might be assumed that a predator had dragged the leg to this position. This is deemed unlikely, however, because the bones have not been broken or even disarticulated. G. E. Lewis (oral commun., 1970) suggested that the displaced bones were shifted by movement of windblown silt. None of the skeletons showed evidence of disturbance by predators, or even of gnawing by rodents. Burial must have been very rapid to have avoided this.

\section{POSITIONS OF THE SKELETONS}

Although several herds or family groups of Platygonus compressus have been discovered, the postures and relative positions of the skeletons have not been described in detail, and none of the groups has been preserved with the skeletons in their original poses. A group of Platygonus pearcei Gazin from the Hagerman Lake Beds of Idaho (Gazin, 1938), consisting of an adult and two young individuals, has been preserved in the position in which found (USNM 13800). Gazin figured these specimens but did not discuss their poses. Accordingly, it seems worthwhile to describe, as well as figure, the positions of the Hickman peccary group. The skeletons are preserved in the U.S. National Museum (USNM 26098-26102) in the positions in which they were found.

\section{SKELETON 1}

Skeleton 1 (figs. 9, 10) is lying on its right side. The right side (underside) of the skull seems to have been crushed, inasmuch as the right temporal condyle has been rotated downward and outward and turned $180^{\circ}$. The neck is flexed to the right (downward), probably by the weight of the overlying material. The atlas has been disarticulated from the occipital condyles and moved to the right (downward) about $70 \mathrm{~mm}$. With only slight gaps, the vertebrae are articulated from the atlas to the third caudal; two other caudal vertebrae, separate but articulated with each other, lie beside the third caudal. The anterior part of the back is lying on its side, in the same plane as the head. Between the 10th thoracic vertebra (most posterior one with a long neural spine) and the 11th, rotation has occurred; posterior to the 11th thoracic vertebra the neural spines are vertical. The pelvis, which is in normal articulation with the sacrum, is positioned with its dorsal side up. The posterior half of the vertebral column is 


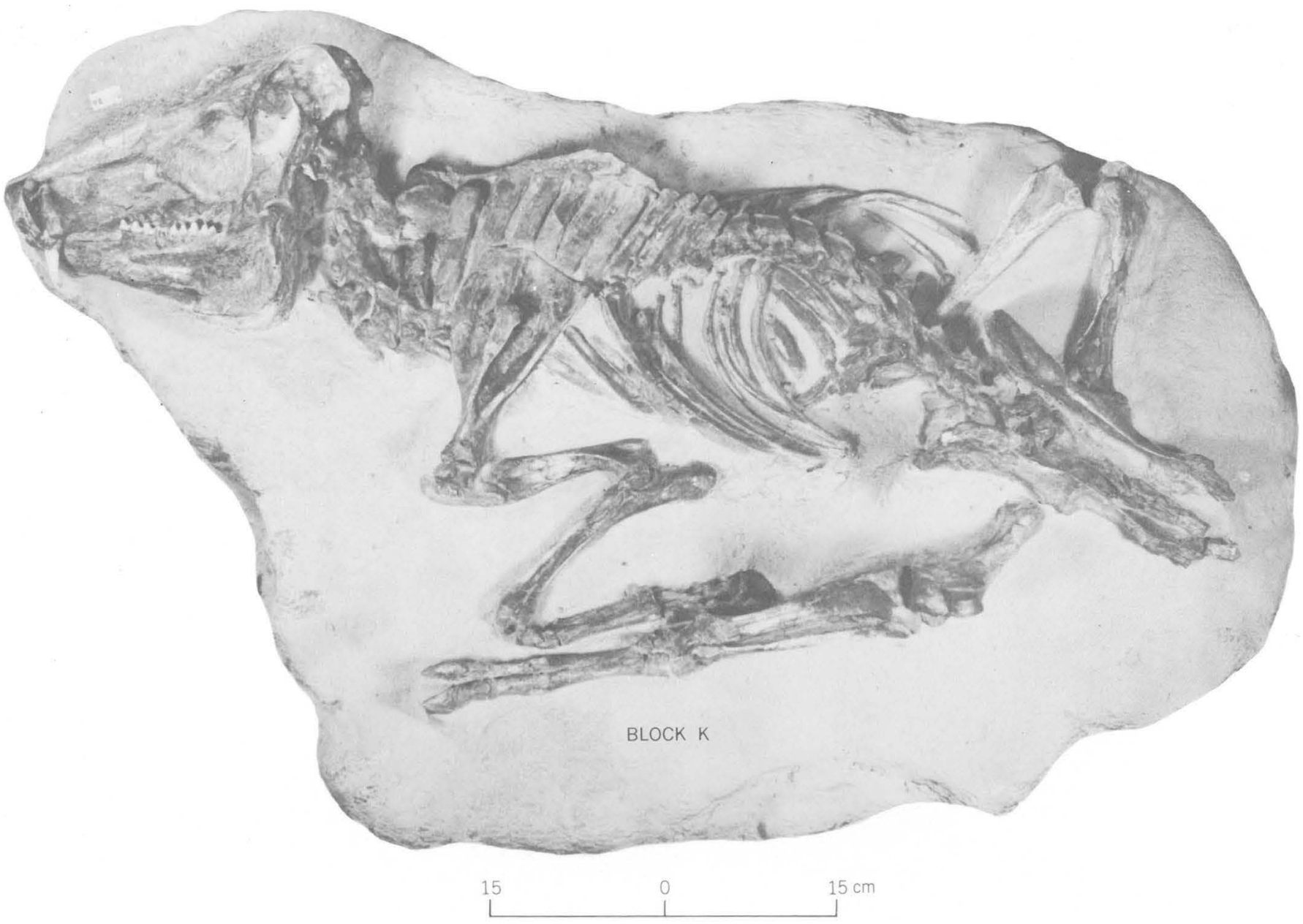

Figure 10. - Peccary Platygonus compressus, skeleton 1, in natural position.

probably in the position the animal assumed just before death. The hyoid bone is approximately in place at the level of the posterior border of the mandible. Because of the decision to leave the skeleton in death position, the hyoid could not be exhumed, but the posterior $35 \mathrm{~mm}$ of the right thyroid cornu is exposed. It is $3.5 \mathrm{~mm}$ in diameter. The hyoid has been rotated so that its right side is about $15 \mathrm{~mm}$ lower than its left side.

The left femur is in almost natural articulation with the pelvis. The tibia is slightly twisted out of articulation at the knee. The rest of the left hindlimb is in normal articulation. The right femur has moved outward and downward from a normal crouching position so that the femur lies with its medial side up, rotated in the acetabulum beyond the position of normal articulation. The tibia is in normal articulation with the femur. The patella is present, only slightly out of position. The rest of the right hindlimb is buried beneath the lumbar region.

The left front limb is in normal flexed position. The carpals are slightly disarticulated from the ulno- radius. The right scapula is rotated upward and forward so that its neck is at the level of the seventh cervical vertebra and $120 \mathrm{~mm}$ above its centrum. The head of the right humerus is in contact with the glenoid cavity of the scapula but is disarticulated and rotated backward so that it is parallel to the vertebral column.

On the humerus, the line of the proximal epiphysis is visible; the distal epiphysis is closed. The radius and ulna are fused. Both epiphysis of the radius are closed. The olecranon epiphysis of the ulna is barely visible. The epiphysis of the metacarpus and of the first and second phalanges of the forelimb are fused. The main pelvic bones are fused, but the ilium is not fused to the tuber coxae, and the tuber ischii is not fused to the ischium. On the femur, the proximal epiphysis is not clearly visible; the distal epiphysis is still visible but is probably nearly closed. On the tibia, the proximal epiphysis is fused; the bone is cracked at the distal end so that it is impossible to be sure of the condition of the epiphysis. The metatarsal epiphyses are fused. 
$\mathrm{M}_{3}$ and probably $\mathrm{M}^{3}$ are fully erupted. $\mathrm{M}_{2}$ and $\mathrm{M}_{3}$ are slightly worn. $\mathrm{M}_{1}$ is worn to concavity. $\mathrm{P}_{3}$ and $\mathrm{P}_{4}$ are worn so that the dentine shows. $\mathrm{P}_{2}$ is only slightly rounded by wear. There is heavy wear on the canines.

According to the age criteria developed by Kirkpatrick and Sowls (1962) on the basis of tooth eruption in the collared peccary (Tayassu tajacu), skeleton 1 represents an individual more than 74 weeks old.

SKELETON 2

Skeleton 2 (fig. 11), like skeleton 1, represents an individual that seems to have died lying in a natural position on its ventral side, with forelimbs flexed under it and probably with chin resting on the ground. In contrast to skeleton 1, the skull of skeleton 2 rests on its left side. The cervical vertebrae have been displaced ventrally (horizontally) about $80 \mathrm{~mm}$. All vertebrae are in articulation from the atlas to about the fourth thoracic; there the vertebrae are disarticulated, with the anterior surface of the centrum of the fifth thoracic vertebra at an angle of about $100^{\circ}$ to the posterior surface of the fourth thoracic (fig. 11). The attitude of the posterior thoracic vertebrae cannot be seen, but the ribs protruding from the matrix are in sequence, implying that the corresponding vertebrae are in or near articulation. Six lumbar vertebrae are in articulation. Most of the sacrum has been lost, but parts of three sacral vertebrae, which had been linked only by cartilage, were collected with the skeleton.

The scapulae are approximately in place. The forelimbs are not visible. The hindlimbs are in place. The pelvis is separated into right and left halves, and the two parts are out of orientation with each other (fig. 11). From the orientation of the hindlimbs, it appears that they were spraddled much like those of skeleton 1 . The right femur is rotated backward and lies on its anterior side in a position that suggests that it was in or near articulation with the acetabulum. The right tibia has been dislocated from the femur and moved forward $45 \mathrm{~mm}$ from the distal end of the femur (fig. 11). The tibia, tarsus, and metatarsus are articulated; the phalanges, if pres-

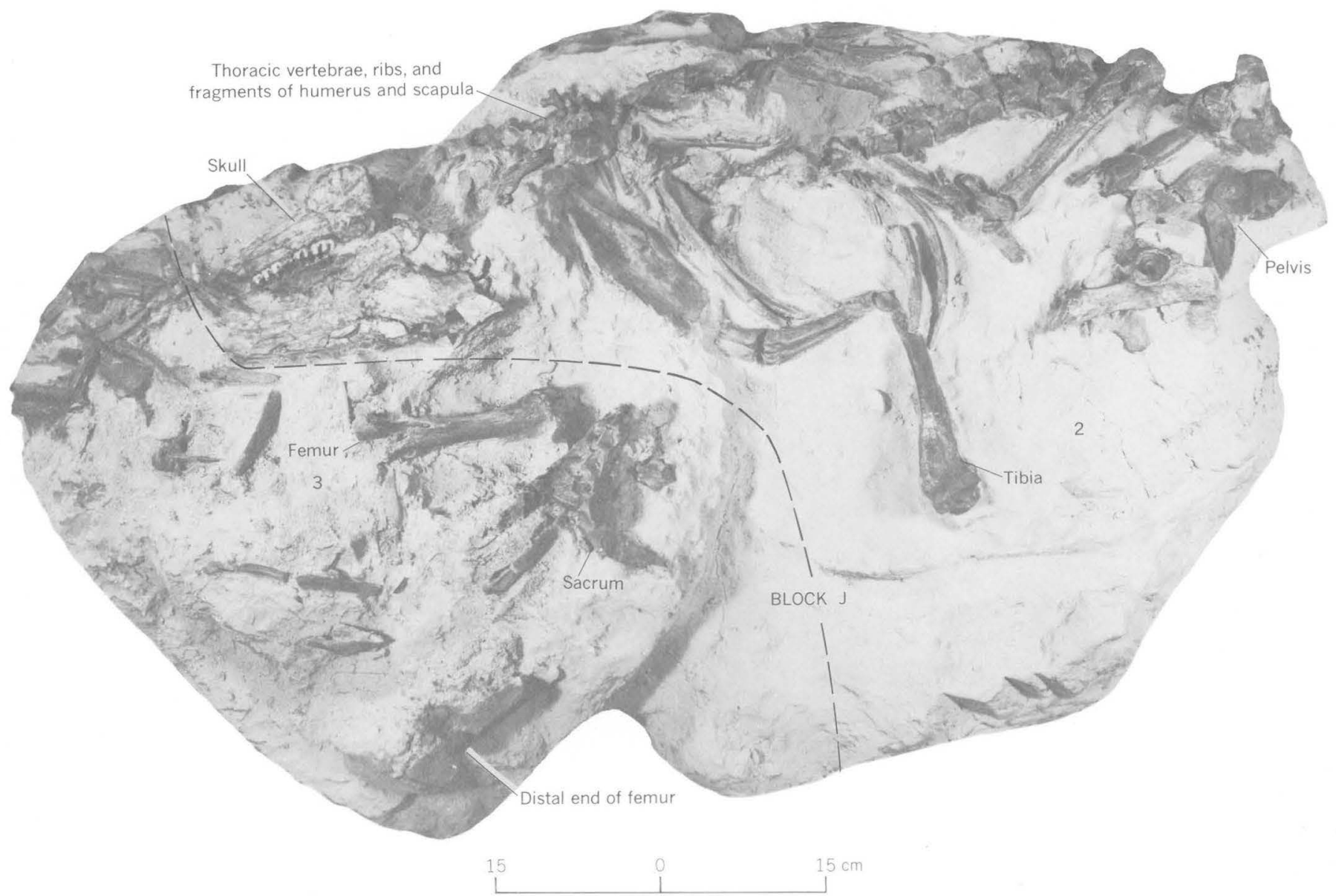

Figure 11. - Peccary Platygonus compressus, skeleton 2 and posterior part of skeleton 3 (lower left part of block), in natural position. 
ent, are embedded beneath the anterior end of the lumbar series. The left hindlimb is articulated. Both hindlimbs are flexed.

The epiphyseal sutures are closed on the hindlimbs, except for the distal ends of the tibiae, where they are open. Epiphyses are open at the ends of the centra of the thoracic vertebrae; they probably are closed on the lumbars.

The upper dentition is not visible. $\mathrm{M}_{3}$ is erupted and slightly worn. $\mathbf{M}_{2}$ has about the same wear as $\mathrm{M}_{3} . \mathrm{M}_{1}$ is worn, and concavity was just beginning. $\mathrm{P}_{4}$ is slightly worn; $\mathrm{P}_{2}$ and $\mathrm{P}_{3}$, less so. The anterior side of the upper canine is considerably worn.

Skeleton 2 represents an individual younger than that of skeleton 1 but is judged to be still older than 74 weeks on the basis of tooth eruption.

SKELETON 3

Skeleton 3, though articulated at burial, is less nearly complete than skeletons 1 and 2 . It was collected in several pieces: posterior part from the left end of block J (fig. 11), anterior part from the right end of block A (fig. 12), and isolated bones from north of blocks A and B (fig. 9). A sacrum comprised of four vertebrae, lies $150 \mathrm{~mm}$ north of the skull of skeleton 2 (fig. 11). The right femur is in proper position for articulation (fig. 11) though the pelvis is not in place-iliac blades collected separately probably represent the pelvis of this individual. The distal epiphysis of this femur is open. A femur, tibia, ulno-radius, and two pelvic fragments (fig. 9) that are isolated from the other bones of skeleton 3 may belong to that skeleton.

Two thoracic vertebrae, with open epiphyses on their centra, the distal end of another femur (fig. 11), with epiphysis closed, and several ribs are also present.

At the west end of block A, $38 \mathrm{~cm}$ left of the east end of block J, are an articulated scapula, humerus, and fused radius and ulna (fig. 12), all with epiphyses closed and in extremely flexed position. East of these are articulated cervical vertebrae 2 through 7 , with 7 in contact with the head of the humerus (fig. 12). The anterior spine of the axis vertebra lies only about $10 \mathrm{~mm}$ from the foramen magnum of the skull. The atlas was displaced but lay near the other

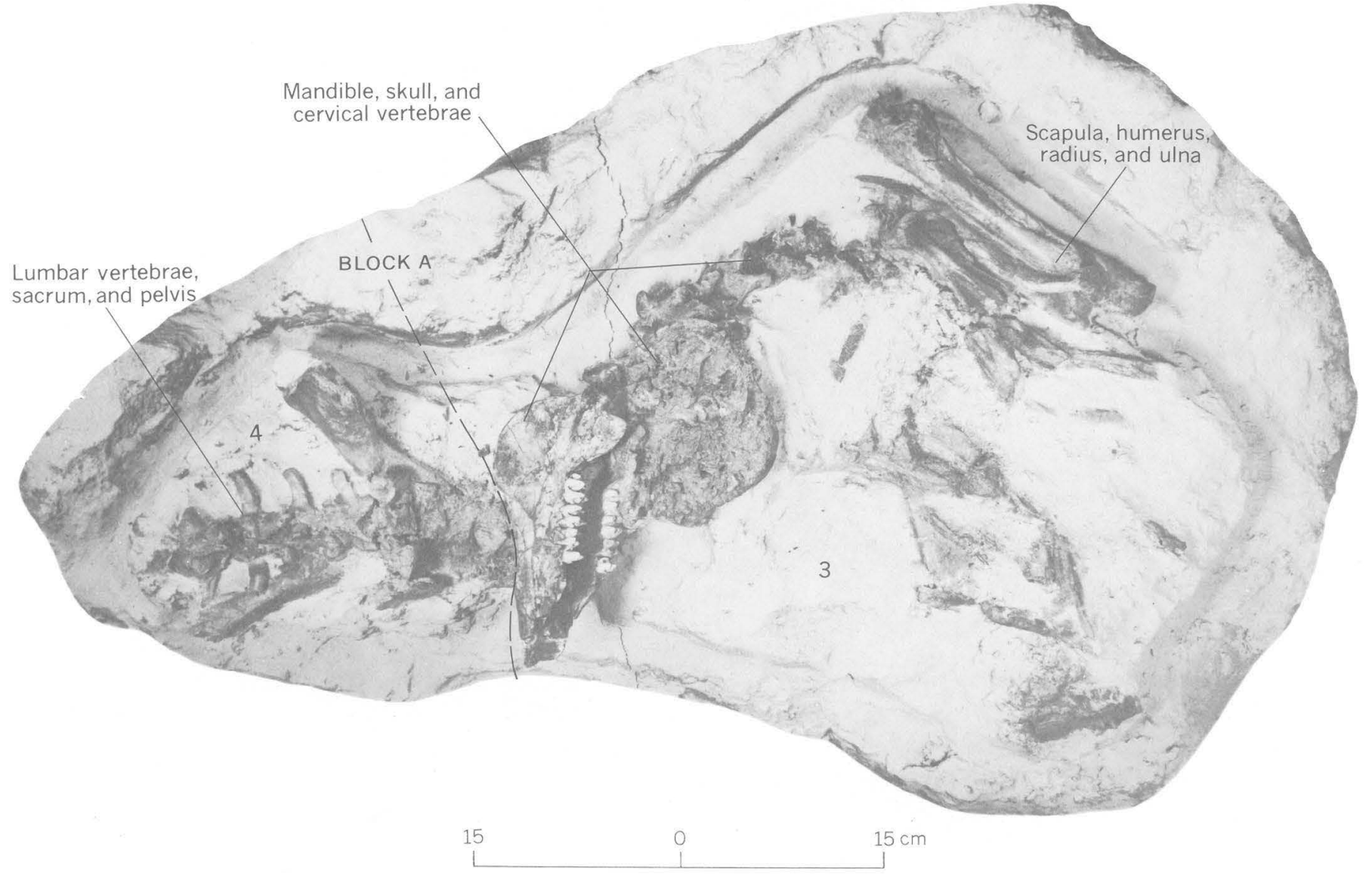

Figure 12. - Peccary Platygonus compressus, anterior part of skeleton 3 (right two-thirds of block) and posterior part of skeleton 4 (left part of block), in natural position. 
cervical vertebrae; it was removed during excavation. Most of the cranium of this individual was destroyed, probably by the first pass of the bulldozer blade at the time of discovery. However, a partial maxilla was recovered, bearing $\mathrm{P}^{3}, \mathrm{M}^{1}$ and $\mathrm{M}^{2} . \mathrm{P}_{3}$ is almost unworn; $\mathrm{P}^{+}$is missing-no alveolus is present and the position of $\mathrm{P}^{4}$ is represented only by a gap of $7.3 \mathrm{~mm}$ between $\mathrm{P}^{3}$ and $\mathrm{M}^{1}$. $\mathrm{M}^{1}$ is worn to concavity; in $\mathbf{M}^{2}$, the anterior loph is appreciably worn, and the posterior loph is fresh. The mandible is present, nearly in articular position with the skull; its anterior end is broken off $30 \mathrm{~mm}$ anterior to the posterior end of the symphysis. $P_{2}$ is missing, and the part of the mandible bearing it is chipped away. The right $P_{3}$ is missing; its alveolus indicates a small tooth (table 1 ). The right $P_{4}$ is present, is fully erupted, and is only very slightly worn. The right $\mathbf{M}_{1}$ is slightly worn. $\mathrm{M}_{2}$ and $\mathrm{M}_{3}$ of both sides are present.
$\mathrm{M}_{2}$ is in beginning wear; $\mathrm{M}_{3}$ is unworn, not quite erupted.

Skeleton 3, on the basis of tooth eruption, is believed to represent an individual of about the same age as that of skeleton 2 .

\section{SKELETON 4}

Skeleton 4, like skeleton 3 , is divided between two blocks (figs. 9, 12, 13). The pelvis of skeleton 4 (fig. 12) was in contact with the skull of skeleton 3 . The basal part of the sacrum is present and in place, but the tops of the sacral vertebrae have been destroyed. Four associated and articulated lumbar vertebrae are in place (fig. 12). The central epiphyses of these vertebrae are open, as are those on five thoracic vertebrae, probably from this individual, that were collected loose at the east end of block A. At the south end of block B (almost in contact with the east end

TABLE 1. - Measurements, in millimeters, of skulls, mandibles, and teeth of Platygonus compressus from near Hickman, Ky., and Denver, Colo.

[Specimen numbers: USNM, U.S. National Museum; D, U.S. Geological Survey, Paleontology and Stratigraphy Branch, Denver fossil vertebrate locality.

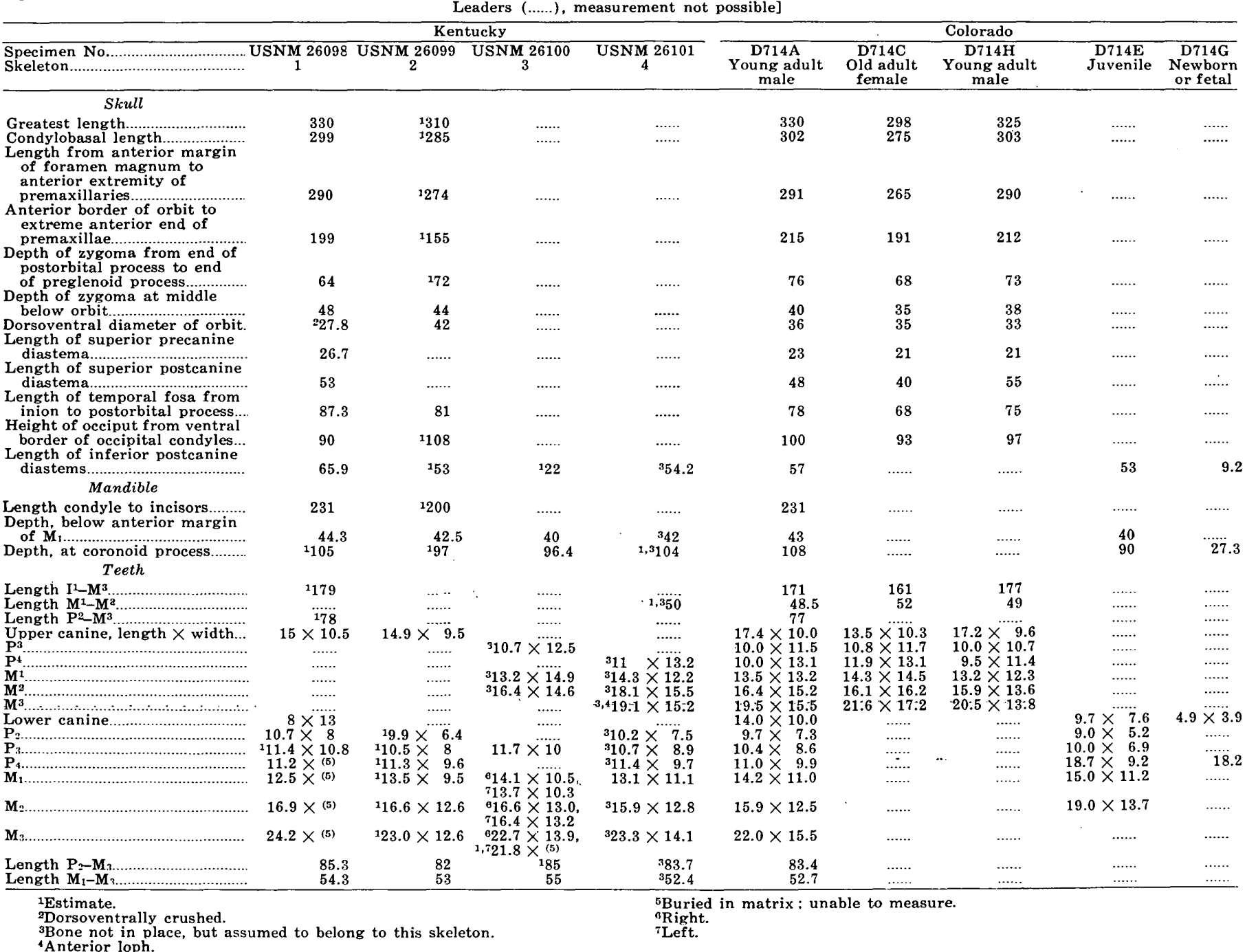


of block A) is a badly broken ulna articulated to a complete lower forelimb (fig. 13), in flexed position. A skull was located immediately north of this (fig. 13) but was broken before the block was removed. Two fragments found at the site of this skull contained, respectively, $\mathrm{P}^{4}$ and $\mathrm{M}^{1}$, and $\mathrm{M}^{2}$ and $\mathrm{M}^{3}$. $\mathrm{P}^{4}$ is only very slightly worn. The anterior loph of $\mathrm{M}^{1}$ is worn to the point of dentine exposure; the posterior loph is only slightly worn. The anterior loph of $\mathrm{M}^{2}$ is slightly worn; the posterior loph is unworn. $\mathrm{M}^{3}$ is unworn and was probably unerupted. Surrounding the site of the skull are two articulated lower hindlimbs (tibia, tarsus, metatarsus, and phalanges; fig. 13). Of these, the tibiae appear to have open epiphyses at both ends; all other epiphyses are closed.

The individual represented by skeleton 4 , on the basis of tooth eruption, is interpreted as younger

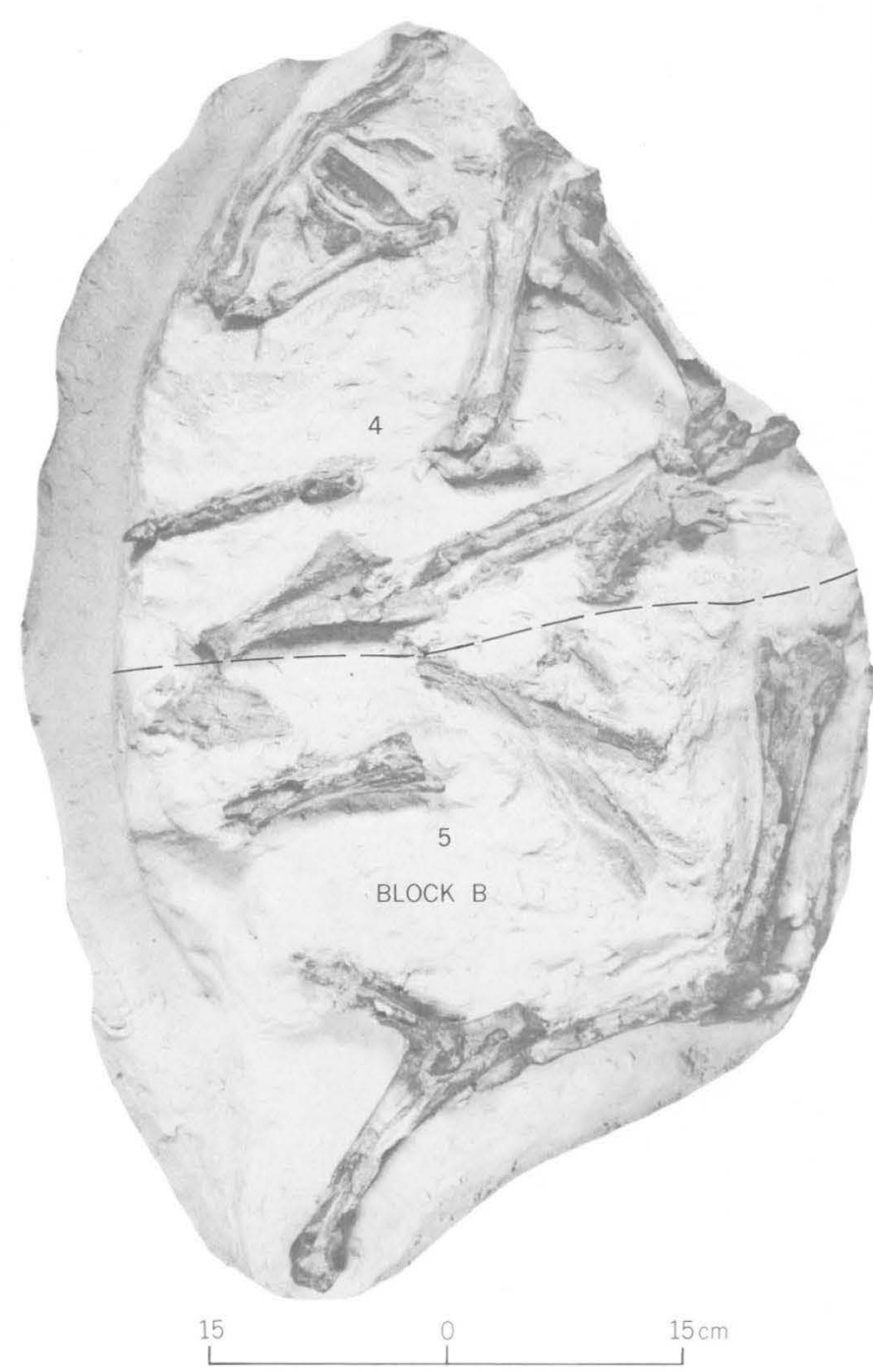

Figure 13. - Peccary Platygonus compressus, parts of skeleton 4 (top) and skeleton 5 (bottom), in natural position. than the individuals represented by skeletons 1,2 , and 3 and as not much older than 74 weeks by the criteria used with Tayassu tajacu, inasmuch as $\mathbf{M}^{3}$ is fully formed but unerupted.

SKELETON 5

Skeleton 5 (figs. 9, 13) is represented by a scapula, part of an articulated hindlimb (tibia, tarsus, metatarsus, and phalanges), and part of an articulated forelimb (distal end of humerus articulated with fused radius and ulna) (fig. 13). The hindlimb is extended and the forelimb flexed-this animal died in the same position as the animal represented by skeleton 1 (figs. 9, 10). The distal epiphysis of the humerus appears to be open; all other epiphyses are closed.

All that can be said on the basis of the limbs of skeleton 5 is that the individual was probably an adult. A right mandible found near block A (fig. 9) must belong with either skeleton 4 or skeleton 5 . It has a complete cheek-tooth series: $\mathrm{P}_{2}$ and $\mathrm{P}_{3}$ with enamel slightly worn, $\mathrm{P}_{4}$ with dentine showing on the anterior lophid, $\mathbf{M}_{1}$, worn to concavity, $\mathbf{M}_{2}$ with dentine showing on both lophids, and $\mathrm{M}_{3}$ with dentine just beginning to show on the first and second lophids. This would indicate an individual of about the same age as that of skeleton 1 , and the teeth would not match the upper teeth assigned to skeleton 4. The mandible is, therefore, tentatively assigned to skeleton 5 .

\section{COMPOSITION AND INFERRED HABITS OF THE HERD}

All five peccaries were adult. Absolute ages cannot be assigned with confidence, but the relative ages of the individuals are significant because of their association. It is estimated that the herd consisted of two fully adult animals (skeletons 1 and 5), two slightly younger (skeletons 2 and 3), and a still younger animal (skeleton 4), that was nearly full grown. On the basis of size of canines and heaviness of zygomatic arch, skeleton 1 is believed almost certainly to have been a male. On the same basis, skeleton 2 is believed probably to have been a female. The sex of the other skeletons cannot be judged. As found, the skeletons were probably lined up in the order in which they were walking when overwhelmed: the two oldest animals leading and bringing up the rear, respectively; the youngest animal following the leader and the two slightly younger behind it.

Despite morphological differences that certainly indicate contrasts in habit between Platygonus compressus and living peccaries, both forms share the characteristic of gregariousness as indicated by discoveries of herds of Platygonus, cited before. Both the collared peccary (Tayassu tajacu) and the white- 
lipped peccary (Tayassu pecari) run in herds. Harems do not exist; a herd consists of both sexes and all ages, more or less in random combination. The collared peccary has a year-round breeding season (Sowls, 1961). There is no evidence of pairing of males and females for either a short or a long period. Sows appear to have several mates during a single estrous period, and there is no aggressive behavior between males in the herd (Sowls, 1966). In Veracruz, Mexico, the collared peccary usually travels in herds of 5-10 individuals; the white-lipped peccary, in bands of 12-25, with herds of 50 or more reported (Hall and Dalquest, 1963). Leopold (1959, p. 494) pointed out that peccary herds are larger when the population is denser. The collared peccary, in areas of sparse population, runs in herds of two or three up to a half-dozen. In areas of plenty they are seen in groups of 10-20, rarely more. Collared peccaries follow their mothers until at least 1 year old, so smaller herds may well be family groups.

The composition of the Hickman herd of Platygonus compressus is consistent with the loose social organization observed for living peccaries. Skeleton 4 may represent a yearling still following its mother.

Among several structural differences distinguishing Platygonus from living peccaries are longer legs, presence of sharp, high transverse cusps on the cheek teeth, and much larger nasal cavities which have more extensive turbinal bones. As Leidy (1853, p. 325-326) pointed out, the tooth pattern of Platygonus indicates a lower jaw movement that was "less rotary and more simply ginglymoid than exists in Dicotyles; for at the same stage of trituration of the teeth in the latter, the principal lobes would be worn down to a level with the bottom of the interlobular fissures, approaching more in this respect the Hog than the Tapir." The strongly lophodont teeth of Platygonus indicate a diet different from that of Tayassu; G. E. Lewis (written commun., May 1970) has suggested that Platygonus is better equipped to chew harsher vegetation from a different environment than Tayassu, which has a bunodont dentition. The geographic range of Platygonus embraced a more rigorous environment than does that of $\mathrm{Ta}$ yassu, but the range of both genera is latitudinally large enough to show that they share the ability to subsist on a wide variety of food.

The collared peccary is distributed from the Río de la Plata of Argentina, at about lat $35^{\circ} \mathrm{S}$., to southwestern United States at lat $35^{\circ} \mathrm{N}$. This range includes both desert (Sowls, 1961) and tropical forest (Chapman, 1936; although Chapman's paper is titled "White-lipped Peccary," it also records observations of collared peccary herds on Barro Colorado
Island, Canal Zone). Platygonus compressus is known to have ranged from California to New York and from Michigan south at least as far as Florida and Texas (Hibbard and Taylor, 1960, p. 184) ; Ray, Denny and Rubin (1970) reported a specimen that must have died "within a few miles of the wasting late Wisconsinan continental glacier [in Pennsylvania], and [must have] lived there in a periglacial environment."

Leidy also remarked $(1853$, p. $334-335)$ on the "enormous cellular dilatation" between the maxilla and the palatine bones, whose interior communicates anteriorly with the cavity of the nose. The malar bone also has a cellular interior. A set of skulls sagittally sectioned by John E. Guilday showed that Platygonus has a much larger nasal cavity and more extensive turbinal bones than Tayassu or Mylohyus; it also has false internal nares, leading into cul-desacs at the posterior end of the palate (Guilday and others, 1971, p. 304). The passage of air through the nasal passage was thus very tortuous, which may have been an advantage in a dust-laden atmosphere.

Platygonus, unlike Tayassu, adapted to a cold environment, although, as indicated by the southern limits of its range, it also could live in warmer climates. Most occurrences of Platygonus are in areas that were probably characterized by harsh vegetation, such as silica-rich grass, in late Pleistocene time. Tayassu, by contrast, lives in warm climates but can subsist on both tropical and desert vegetation. The cold-climate range of Platygonus implies great differences from Tayassu in pelage and other adaptations to the environment; a comparable contrast is that between the Pleistocene periglacial woolly mammoth and the living elephants of Africa and India.

\section{OTHER HERDS OF PLATYGONUS COMPRESSUS}

We have found eight reports of herds of this species that died together. Two of these consisted of only two individuals each, but they are included because the individuals were lying close together in the pose that is characteristic of larger herds.

DENVER, COLORADO, HERD

G. Edward Lewis (1970) reported a group of Platygonus compressus in eolian sand and silt of late Wisconsinan age (USGS fossil vertebrate loc. D714). Parts of five skulls were found: those of two adult males, an adult female, a juvenile, and either a newborn or a fetal animal. Numerous postcranial bones were found, but it was impossible to determine with which skulls these bones belonged. The proximity of the bones to each other indicates that the individuals constituted a herd. No complete articulated 
skeleton was preserved. Lewis (written commun., 1970) believed that dissociation was accomplished by dune movement, perhaps over a period of years. For this reason, only measurements of individual bones are available, and most bones cannot be referred with certainty to distinct skeletons. Previously unpublished measurements of these bones, furnished by G. E. Lewis, are presented in tables 1 and 2.

\section{GOODLAND, KANSAS, HERD}

One of the best known reports of a herd burial is that of Williston (1894) involving nine skeletons buried in what was almost certainly loess. The animals were facing southwest, with the heads of the hinder ones resting on the posterior parts of those in front. The bones were "all or nearly all in the position in which they had been at the animals' death" (Williston, 1894, p. 23). As in all other excavations of Platygonus compressus herds, the skeletons were collected bone by bone rather than being left in death position. The skeleton of a female was mounted under Williston's direction at the University of Kansas. A second skeleton was assembled and sent to the American Museum of Natural History, and a third was sent to the Carnegie Museum (Peterson, 1914, p. 114) and subsequently to the National Museum of Canada. Presumably the other specimens remained at the University of Kansas. Williston (1894, p. 27) applied the new name Platygonus leptorhinus to the members of this herd. This species has been synonymized with $P$. compressus (Simpson, 1949, p. 22). Williston's type of $P$. leptorhinus bears the University of Kansas Museum number KU 458; the other skeletons of the herd are lumped together under number KU 3108. Williston stated that the animals were of different ages and sexes, but he does not give the number of animals in each category. From the descriptions and measurements in his paper, it is apparent that the herd included two old individuals, one adult female, two adult males, and two young individuals. Of the young, one had only the first molars erupted of the permanent tooth series, and the other still had its deciduous teeth.

SANDUSKY COUNTY, OHIO, HERD

Parts of at least four individuals were recovered in sand, possibly a dune deposit (Hoare and others, 1964). The bones were partially articulated. The skeleton of a mature female (BGSU 2353) was mounted for exhibition. At least one individual (BGSU 2354) was immature, with open epiphyses on the leg bones and vertebrae. The other peccary bones are numbered BGSU 2355. No mention was made of the positions in which the skeletons were found. The specimens are in the collections of the Department of Geology, Bowling Green (Ohio) State University.

$$
\text { READING, OHIO, HERD }
$$

We thank Mrs. Elizabeth Dalvé of the University of Cincinnati for information concerning one peccary skeleton (UC 40311) and part of a second (UC 40312) excavated by her in 1948 and for permission to measure the complete skeleton, which is mounted in the University of Cincinnati Museum. The skeletons were found on the Albert Stegmann farm, Cooper Road, just northeast of Reading. They were about 6.5 feet $(2 \mathrm{~m})$ below the surface in what appears to be an area of lateral outwash from kame deposits. The altitude of the kame terrace is approximately 635 feet $(195 \mathrm{~m})$ above sea level, in contrast to the common 800 -foot $(245 \mathrm{~m}$ ) altitude of the bedrock hills of the region and the 580-foot $(175 \mathrm{~m})$ altitude of the terrace in Reading of latest Wisconsinan age. Mrs. Dalvé pointed out that more than 11/2 skeletons may have been present, but that excavation had to be discontinued owing to danger of collapse of the trench wall.

$$
\text { COLUMBUS, OHIO, HERD }
$$

Twelve skeletons were found in 1873 "embedded in calcareous clay, intermingled with a very generous quantity of calcareous sand" (Klippart, 1875). Six of the smallest animals were found together at a depth of 8 feet $(2.4 \mathrm{~m})$; the six larger animals were 6 feet $(1.8 \mathrm{~m})$ from the first group and 4 feet $(1.2 \mathrm{~m})$ deeper. Klippart reported that "the strata immediately above the remains were confused, presenting evidence of disturbance so far as the deposition of sand and gravel were concerned, whilst the overlying clay was, so far as the eye could discern, entirely intact or undisturbed." This stratigraphic situation could result from the burial of the peccaries in the cave-in of a bluff under which they had taken shelter; the overlying undisturbed clay could be an alluvial deposit laid down on top of the landslide material at a later time. The animals were lying side by side with their heads toward the southeast, the same orientation as the Hickman peccaries. The bones were entire except where broken from "manifest pressure," and Klippart could find no evidence of the bones "having been gnawed, or "crunched." He reported that nearly all the "bases" and "heads" of the femora, humeri, ulnae and other bones became separated from the shafts while the bones were being boiled in glue. This indicates the presence of a number of juveniles considerably less than a year old, which is to be expected in so large a herd. Half the specimens were apparently sent to O.C. Marsh at 
Yale (Hay, 1923, p. 214). One skull and one mandible (USNM 16557) are in the U.S. National Museum.

BELDING, MICHIGAN, HERD

Wagner (1903) reported on five skeletons in the museum of the University of Michigan. He reported that they had been found in a peat bog, but C. W. Hibbard and R. E. Eshelman, in restudying the specimens, have determined that they came from upland loess (Eshelman, written commun., Mar. 8, 1972). No record had been made of the positions of the skeletons when found. The group contains one adult whose skull sutures are obliterated. The skeleton of this individual (V7325) was mounted at the University of Michigan and was figured by Case (1921, p. 295). Wagner identified this specimen as a female, but Hibbard and Eshelman identify it as a male. The other skeletons are incomplete, and Wagner did not mention the age or sex of the individuals. Hay (1923, p. 216) pointed out that the Belding herd was found close to a part of the Charlotte moraine system of Wisconsinan age.

GAINESVILLE, NEW YORK, HERD

Two skeletons were found in a sand and gravel bank (Clarke, 1916). One belonged to an older individual; the other, to a younger, though grown, specimen which, according to Clarke, still had its temporary molar teeth. No mention was made of the position of the skeletons, which were disturbed before being collected, inasmuch as many of the bones had been carried away with sand for mixing concrete. The recovered bones were placed in the New York State Museum (N.Y.S.M. V41a and V41b). Hartnagel and Bishop (1922, p. 85) stated that the Gainesville skeletons were found in a drumlin less than 1 mile south of the Silver Springs-Rock Glen kame area, in a pocket of sand with clasts "up to one foot in diameter, those of three to four inches in diameter being most abundant." This depositional environment is reminiscent of that reported by Ray, Denny, and Rubin (1970) for a skeleton of Platygonus compressus from Mosherville, Penn.

PITTSFORD (?), NEW YORK, HERD

Leidy (1889) reported the occurrence of two adult individuals, one represented by the greater part of a skeleton and the other by a skull. They were found in a gravel bank. Leidy did not mention the orientation or position of the skeleton. The specimens were deposited in the Academy of Natural Sciences in Philadelphia (skull, ANSP 11544; postcranial bones, ANSP 11545).

\section{SIZE DISTRIBUTION IN PLATYGONUS COMPRESSUS}

Herds such as the Hickman group, found buried together, are helpful as indicators of the size range that existed in groups of known contemporaneity and probable blood relationship. Although several such groups are known, as described above, available measurements are few. Measurements of the Hickman herd are presented in tables 1 and 2 together with measurements of the Denver herd. Publication of measurements of other existing groups would be useful in determining whether population differences can be discerned, and possibly correlated with ecologic conditions, over the wide geographic range of this species. Table 3 reproduces measurements, all made from articulated skeletons of $P$. compressus, for comparison with measurements of the members of the Hickman herd. Other measurements are available in the sources cited; those reproduced here were chosen because they may be indicators of body size. Only for the Goodland, Kans., herd (Williston, 1894) and the Denver, Colo., herd (tables 1 and 2) were measurements for more than one skeleton available. The Goodland and Denver herds differed from the Hickman herd in that they contained juveniles. For the Goodland herd, Williston presented postcranial measurements of only two members, an adult male and an adurt female (1894, p. 27-28). The adult female was mounted for exhibit at the University of Kansas. A composite skeleton, including an immature skull, was traded to the Carnegie Museum where it was mounted (CM 2806; Peterson, 1914); later it was transferred to the National Museum of Canada (NMC 17912).

The upper dentition of NMC 17912 consists of $\mathrm{dP}^{1,2,3}, \mathrm{M}^{1}$ just coming into wear, $\mathrm{M}^{2}$ erupted but unworn, and $\mathrm{M}^{3}$ unerupted. In the lower dentition, $\mathrm{P}_{2}$, $P_{3}$, and $P_{4}$ are beginning to erupt (the milk teeth have been shed), $M_{1}$ is slightly worn, $M_{2}$ is erupted but unworn, and $M_{3}$ is unerupted. The following measurements were made by Whitmore: $\mathrm{dP}^{1}-\mathrm{M}^{2}$, $56.2 \mathrm{~mm}$; $\mathrm{M}^{1}-\mathrm{M}^{3}, 44.1 \mathrm{~mm}$; $\mathrm{C}-\mathrm{M}^{3}, 129 \mathrm{~mm}$; upper diastema, $43.5 \mathrm{~mm}$. Despite the composite nature of the National Museum of Canada skeleton, measurements are included in table 3 as indicative of the size range represented by the members of the Goodland herd.

Another skeleton from the Goodland herd was forwarded in exchange to the American Museum of Natural History, New York (AMNH 10388). Simpson $(1949$, p. 38-44) published measurements of the cheek teeth of this specimen which indicate that it was fully adult. The American Museum skeleton is probably a composite, although this is nowhere 
TABLE 2. - Measurements, in millimeters, of postcranial skeletons of Platygonus compressus from near Hickman, Ky., and Denver, Colo.

\begin{tabular}{|c|c|c|c|c|c|c|c|c|c|c|c|c|}
\hline \multirow{3}{*}{$\begin{array}{l}\text { Specimen No } \\
\text { Skeleton }\end{array}$} & \multicolumn{5}{|c|}{ Kentucky } & \multicolumn{7}{|c|}{ Colorado } \\
\hline & \multirow{2}{*}{$\begin{array}{c}\text { USNM } \\
26098 \\
1\end{array}$} & \multirow{2}{*}{$\begin{array}{l}\text { USNM } \\
26099 \\
2\end{array}$} & \multirow{2}{*}{$\begin{array}{c}\text { USNM } \\
26100 \\
3\end{array}$} & \multirow{2}{*}{$\begin{array}{l}\text { USNM } \\
26101\end{array}$} & \multirow{2}{*}{$\begin{array}{c}\text { USNM } \\
\underset{5}{5}\end{array}$} & \multirow{2}{*}{$\begin{array}{l}\text { D714A } \\
\text { Young } \\
\text { Adult } \\
\text { Male } \\
\end{array}$} & \multirow{2}{*}{$\begin{array}{l}\text { D714B } \\
\text { Imma }\end{array}$} & \multirow{2}{*}{$\begin{array}{l}\text { D714D1 } \\
\text { re }\end{array}$} & \multirow{2}{*}{$\begin{array}{c}\text { D714D2 } \\
\text { old }\end{array}$} & \multirow{2}{*}{$\begin{array}{l}\text { D714F1 } \\
\text { Juvenile }\end{array}$} & \multirow{2}{*}{$\begin{array}{c}\text { Di14F2 } \\
\text { Adult }\end{array}$} & \multirow{2}{*}{$\begin{array}{l}\text { D714F3 } \\
\text { Newborn } \\
\text { or fetal }\end{array}$} \\
\hline & & & & & & & & & & & & \\
\hline $\begin{array}{l}\text { Vertebrae: } \\
\text { Greatest width of atlas }\end{array}$ & & & & & & & & & & & & \\
\hline & $\ldots \ldots$. & $\cdots \cdots$. & 51.7 & $\cdots \ldots$. & $\cdots \ldots$. & $\begin{array}{r}114.5 \\
55.3\end{array}$ & $\cdots \cdots .$. & $\cdots \ldots$. & $\cdots \cdots$. & $\cdots \cdots$. & $\cdots \cdots$. & $\cdots \cdots$. \\
\hline $\begin{array}{l}\text { Height of seventh cervical vertebra, tip of neural } \\
\text { spine to anteroventral extermity of centrum }\end{array}$ & 103.3 & & & & & & & & & & & \\
\hline 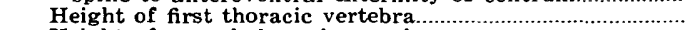 & 151 & 1140 & ........ & & ........ & $\ldots . .$. & ........ & ........ & …..... & $\ldots \ldots .$. & ........ & ........ \\
\hline Height of second thoracic vertebra.. & 162 & 1127 & ....... & $\ldots \ldots$ & ........ & ........ & …... & ….... & ….... & $\ldots \ldots$. & ....... & ….... \\
\hline Height of last lumbar vertebra & ${ }^{157}$ & 63.1 & & 153 & $\ldots \ldots$. & ...... & ....... & ...... & ....... & ...... & ....... & ....... \\
\hline $\begin{array}{l}\text { Length of sacrum (five vertebrae) } \\
\text { Scapula: }\end{array}$ & 131 & ${ }^{1} 165$ & ${ }^{1} 128$ & ...... & ...... & ...... & ...... & $\cdots \cdots$ & $\ldots . .$. & ....... & ....... & ....... \\
\hline Length. & 207 & ${ }^{1} 180$ & $\ldots \ldots$. & ........ & & $\cdots$ & $\ldots \ldots .$. & $\ldots \ldots$. & $\ldots \ldots .$. & $\ldots \ldots$. & $\ldots \ldots .$. & ${ }^{153}$ \\
\hline Width... & 118 & 195 & (n) & ........ & 180 & ....... & ....... & ....... & …..... & ....... & ........ & ........ \\
\hline Anteroposterior diameter of glenoid surface & 28.3 & $\ldots \ldots$ & 27.7 & ....... & 23.4 & ....... & ....... & ....... & ....... & $\ldots . .$. & ....... & ....... \\
\hline $\begin{array}{l}\text { Transverse diameter of glenoid surface................................. } \\
\text { Least anteroposterior diameter of neck }\end{array}$ & 22 & & 22.4 & ..... & 19.1 & $\ldots \ldots$ & ....... & ...... & ....... & ...... & $\ldots \ldots$ & ....... \\
\hline $\begin{array}{l}\text { Least anteroposterior diameter of neck..................... } \\
\text { Greatest anteroposterior diameter of neck distally, }\end{array}$ & & 122 & 22.8 & ...... & 21 & …... & ...... & ...... & ...... & ...... & $\cdots \cdots$ & ...... \\
\hline including supraglenoid tubercle & 36.4 & $\ldots \ldots$. & 33 & $\ldots \ldots$. & 26.4 & ........ & ....... & $\ldots \ldots$. & $\ldots \ldots$. & ....... & $\ldots \ldots$. & ....... \\
\hline s & 206 & & ${ }^{1} 191$ & & & & & & & & & \\
\hline $\begin{array}{l}\text { Length from head to posterior process of inner condyle. } \\
\text { Anteroposterior diameter of shaft just below }\end{array}$ & 188 & $\cdots \cdots$. & 1185 & $\cdots \cdots$. & $\cdots \cdots .$. & $\cdots . .$. & $\cdots \cdots$. & $\cdots \cdots$. & $\cdots \cdots .$. & $\cdots \cdots .$. & $\cdots \cdots$. & $\cdots \cdots$. \\
\hline $\begin{array}{l}\text { Anteroposterior dameter or shart just below } \\
\text { deltoid tubercle }\end{array}$ & 139 & $\cdots \cdots$. & 125 & $\ldots \ldots .$. & & & 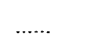 & $\ldots \ldots$. & $\ldots \ldots .$. & $\therefore \ldots$. & $\ldots \ldots$. & $\ldots \ldots . .$. \\
\hline Maximum breadth near distal end, across epicondyles... & ${ }_{142}^{14}$ & ....... & 145 & ....... & 40.2 & ........ & $\ldots \ldots .$. & ........ & ....... & $\ldots \ldots$. & ........ & ….... \\
\hline $\begin{array}{l}\text { Maximum breadth of distal articulation.......................... } \\
\text { Length of ulna }\end{array}$ & ${ }_{02}^{137}$ & ...... & 135 & ...... & 33.2 & ....... & ....... & ...... & $\ldots \ldots$. & & $\ldots \ldots$ & ........ \\
\hline $\begin{array}{l}\text { Length of ulna } \\
\text { Length of radius. }\end{array}$ & 222 & ...... & $\begin{array}{r}226 \\
1165\end{array}$ & $\cdots \cdots \cdot$ & 221.5 & ........ & ....... & ...... & $\cdots \cdots$ & 213 & ....... & 78 \\
\hline $\begin{array}{l}\text { Length of radius } \\
\text { Width of sigmoid fossa }\end{array}$ & 100 & ....... & $\begin{array}{r}1165 \\
135\end{array}$ & $\cdots \cdots \cdot$ & $\begin{array}{r}160.5 \\
29.4\end{array}$ & …... & …... & ....... & ...... & 159 & ...... & 68 \\
\hline Least width of conjoined radius and ulna & ${ }_{20}^{32.3}$ & $\ldots \ldots .$. & 125 & $\ldots \ldots .$. & 24.2 & …... & ........ & $\ldots . . .$. & $\cdots \cdots .$. & 30.8 & $\cdots \cdots$. & $\begin{array}{ll}10 \\
\ldots \ldots\end{array}$ \\
\hline $\begin{array}{l}\text { Greatest breadth of distal portion of conjoined radius } \\
\text { and ulna. }\end{array}$ & 143 & & 43.5 & & 38.5 & & & & & $452,2>-3>0$ & & \\
\hline Ulno-radius, greatest breadth of distal articular surface........ & 33 & ....... & 134.0 & ........ & $\begin{array}{lll}32.1 & 0.0 \\
32.1 & & \end{array}$ & ....... & ….... & ….... & $\ldots \ldots .$. & 44.5 & ........ & $\ldots \ldots .$. \\
\hline 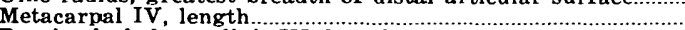 & 92.1 & ........ & ....... & 80.4 & ........ & 98.8 & & 98.2 & ....... & 92.0 & $\cdots \cdot$. & ....... \\
\hline 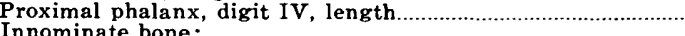 & & $\ldots \ldots .$. & ....... & 36.6 & ....... & 39.5 & 38.0 & $\ldots . . .$. & ........ & 39.7 & 41.0 & ........ \\
\hline $\begin{array}{l}\text { Innominate bone: } \\
\text { Greatest length }\end{array}$ & & 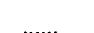 & & & & & & & & & & \\
\hline Center of acetabulum to anterior border of ilium............. & 129 & $\ldots \ldots .$. & ......... & $\ldots \ldots .$. & ........ & $\ldots \ldots$. & ........ & ….... & ….... & $\ldots \ldots .$. & ….... & …... \\
\hline Center of acetabulum to posterior border of ischium....... & 124 & 1120 & …... & ….... & ........ & ........ & ........ & ........ & ….... & ........ & ….... & ........ \\
\hline Diameter of acetabulum & 25.4 & 27.4 & ....... & ....... & $\ldots \ldots$ & $\ldots \ldots$ & $\ldots \ldots$ & $\ldots \ldots$ & ...... & ...... & $\ldots \ldots$ & $\ldots \ldots$ \\
\hline $\begin{array}{l}\text { Longest diameter of obdurator foramen........ } \\
\text { Femur. }\end{array}$ & ...... & ${ }^{146}$ & ...... & $\cdots \cdots \cdot$ & ...... & $\cdots \cdots \cdot$ & ....... & $\cdots \cdots$. & $\cdots \cdots \cdot$ & $\cdots \cdots \cdot$ & $\cdots \cdots$ & ...... \\
\hline Length... & 201 & 2195 & 180 & 1,2180 & & $\ldots \ldots$ & $\ldots \ldots$ & $\ldots \ldots$ & $\ldots \ldots$. & $\ldots \ldots$. & $\ldots \ldots$. & $\ldots \ldots$. \\
\hline iameter of he & ........ & 227.3 & 127 & 225.9 & 227 & ....... & ...... & ....... & ....... & ....... & $\ldots \ldots$. & $\ldots \ldots$ \\
\hline $\operatorname{Tr}$ & & $\begin{array}{l}232.5 \\
248\end{array}$ & $\begin{array}{l}125 \\
132\end{array}$ & ${ }^{2} 31.6$ & $\begin{array}{l}{ }_{247.3}^{3} .5 \\
247-10\end{array}$ & .... & ....... & ...... & ...... & ...... & $\cdots \cdots$ & $\cdots \cdots$ \\
\hline $\begin{array}{l}\text { Transv } \\
\text { Transv }\end{array}$ & 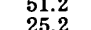 & $\begin{array}{l}-48 \\
223,3\end{array}$ & 32 & …. & $\frac{24.3}{225}$ & ...... & $\cdots \cdots$. & $\cdots \cdots$ & $\cdots \cdots \cdot$ & ...... & $\cdots \cdots \cdot$ & ...... \\
\hline $\begin{array}{l}\text { Transverse diameter of } t \\
\text { Tribia: }\end{array}$ & & & $\cdots$ & $\cdots \cdot$. & & $\cdots \cdots$ & $\cdots \cdots$ & $\cdots \cdots$ & $\cdots \cdots$ & $\cdots \cdots$ & $\cdots \cdots$ & 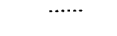 \\
\hline Width of proximal end & $\begin{array}{r}53.8 \\
108\end{array}$ & 14.3 & $\ldots . .$. & 39.6 & 49.2 & $\ldots \ldots$ & $\ldots . .$. & $\ldots \ldots$. & ....... & ...... & $\cdots \cdots$ & 61 \\
\hline $\begin{array}{l}\text { Length } \\
\text { Transerse diameter of distal articulation }\end{array}$ & $\begin{array}{r}198 \\
24\end{array}$ & ${ }_{117}^{189}$ & $\cdots \cdots .$. & $\begin{array}{c}180 \\
21.1\end{array}$ & $\begin{array}{r}1204 \\
124\end{array}$ & …... & $\cdots \cdots$. & ....... & $\cdots \cdots .$. & …... & $\cdots \cdots$ & 61 \\
\hline Fibula, lengt & 178 & & ........ & & ${ }^{1} 179$ & ....... & ....... & ….... & $\ldots \ldots$. & ........ & ....... & ........ \\
\hline $\begin{array}{l}\text { Metatarsal IV, length } \\
\text { Proximal phalanx digit IV Jenoth }\end{array}$ & 92.4 & 190 & $\cdots \cdots$ & 83.2 & & ...... & $\cdots \cdots$ & $\cdots \cdots$ & 96.3 & $\cdots \cdots$ & ....... & …... \\
\hline
\end{tabular}

'Bstimate. not in place, but assumed to belong to this skeleton. 
TABLE 3. - Measurements, in millimeters, indicative of stature of Platygonus compressus, made from articulated skeletons

[Localities listed geographically, from west to east. KU, Museum of Natural History, University of Kansas; NMC, National Museum of Canada; USNM, United States National Museum; UC, University of Cincinnati; BGSU, Bowling Green (Ohio) Shate University; Aniver, Ac

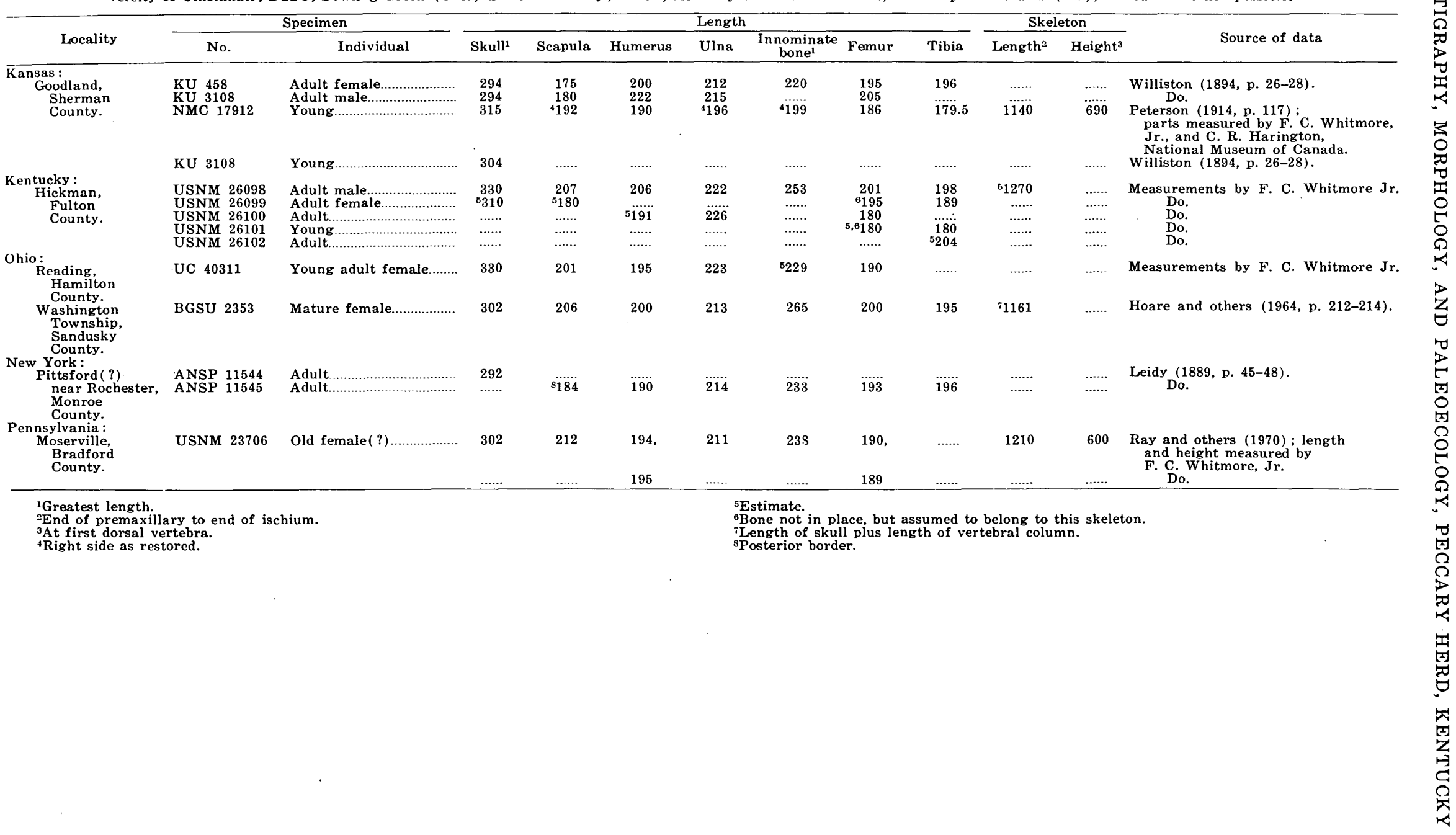


stated. Simpson (1949) compared the American Museum skeleton and Williston's and Peterson's measurements of the Goodland skeletons with his large suite of $P$. compressus bones from Cherokee Cave, St. Louis, Mo. He concluded (p. 44) that

It is nevertheless clear that as populations, that represented by Williston's Kansas specimens is somewhat different from that represented by the series from St. Louis. Their variations fully intergrade, and many individuals could not well be distinguished taken separately, but the mean size of their teeth (and perhaps some other averages for details) are somewhat different. They represent slightly different segments of one specific population.

The Goodland, Hickman, and Denver herds of $P$. compressus are the only ones for which measurements of several individuals are available. In several parameters $\left(\mathrm{P}_{2}-\mathrm{M}_{3}\right.$ length, skull length, scapula length, ulna length), the range of measurements of Hickman bones demonstrates a larger size than does that of bones recovered at Goodland (table 3). Ray, Denny, and Rubin (1970) suggested a clinal decrease in size northward in $P$. compressus. This was indicated by a regular decrease in cheek-tooth length from southwest to northeast, and the cheek-tooth lengths in the Hickman herd fit within this trend. The single upper dentition measured from the Denver herd also fits the trend, but the lower dentition from the Denver herd is larger than would be expected if a cline existed, and it is also unusually large considering the size of the upper dentition (to be compared to Ray and others, 1970 , table 5). Measurements of postcranial elements of articulated skeletons (table 3 ) do not give a clear clinal picture. If the Goodland and Hickman herds are combined and used as a standard of comparison, almost all measurements from the other cited skeletons fall within their range. Total length and height of skeleton, noted in table 3 , should be considered only as approximations because of differences in posture and mounting techniques for exhibit specimens and because of distortion of specimens left in natural position. In most parameters, the Denver herd falls within the size range of the combined Hickman and Goodland herds (tables 1-3; Williston, 1894, p. 2628 ). In length of temporal fossa, however, the largest Denver measurement is smaller than the smallest Hickman measurement and only slightly overlaps the Goodland range (Denver, 68-78 $\mathrm{mm}$; Goodland, $75-82 \mathrm{~mm}$ ). The Denver herd has markedly longer metatarsals and metacarpals than the Hickman herd (table 2), but the proximal limb bones in both herds fall within the same size range.

\section{MOLLUSCA}

Large gastropods ranging from 1.5 to $3 \mathrm{~cm}$ across occur around the peccaries as single shells, in clus- ters of two or more shells $5-10 \mathrm{~cm}$ in diameter, and in layers $2.5-5 \mathrm{~cm}$ thick. One such layer $5 \mathrm{~cm}$ thick at the peccary level was composed of whole and broken shells of Aquispira alternata (Say) that covered an area at least 10 by $30 \mathrm{~cm}$. A few gastropods occurred among the bones of the peccaries.

At the mollusk locality north of the peccary site (fig. 1), Anguispira kochi (Pfeiffer) and the giant Allogona profunda (Say) were found by Mrs. Ruth Browne (written commun., 1967) to be limited to the Farmdale (Roxana as used here), though small Allogona profunda were identified in the lowermost typical Peoria Loess.

\section{AGE OF FOSSILS}

Radiocarbon dating of the peccary bones is not feasible because they are largely replaced by calcium carbonate (Meyer Rubin, oral commun., 1968).

Aragonitic gastropod shells of Anguispira alternata (Say) collected about 4 feet $(1.2 \mathrm{~m})$ above the base of the Roxana and within 50 feet $(16 \mathrm{~m})$ of the peccary skeletons were radiocarbon dated as $>34,000$ years B.P. by Meyer Rubin (sample W-2127, in Sullivan and others, 1970). This date is within Altonian Substage interval of 28,000-70,000 years (fig. 3; Frye and others, 1968). This assignment would hold true even if as much as 3,000 years were subtracted from the radiocarbon date to compensate for possible presence of inorganic carbon incorporated into the gastropod shell. Rubin and Taylor (1963) discussed sources of error in carbon-14 dates determined on shell material.

\section{PALEOECOLOGY AND THE DEATH OF THE HERD}

During Altonian time the glacial front was in the vicinity of Shelbyville, Ill., about 200 miles $(320 \mathrm{~km})$ north-northeast of Hickman. As the glacial ice melted, the resulting streams flowed southward heavily laden with silt. The low-gradient drainage was no doubt poorly defined, giving rise to extensive mudflats and marshlands. The Mississippi is believed to have flowed southward through the Morehouse lowland west of Sikeston, Mo., toward Hickman and at the most only a few miles west of the present Chickasaw Bluffs. Aquatic gastropod fossils found in Roxana Silt just east of the bluffs indicate the presence of another perennial stream in the vicinity of Hickman (Finch, 1971, Roxana description).

The climate and vegetal cover at the time the peccaries roamed the Hickman area can be ascertained from associated fossil material. The large number of Anguispira kochi (Pfeiffer) and large specimens of Allogona profunda (Say) "seems to confirm the presence of true forests during the time of Farmdale 
[Roxana as used here] deposition. Climate was probably somewhat cooler than at present" (Ruth G. Browne, written commun., 1967). Hackberry trees were common and locally abundant. At the peccary horizon and within 50 feet $(15 \mathrm{~m})$ a vertical zone about $1 \mathrm{~cm}$ wide, $30 \mathrm{~cm}$ long, and $2.5-8 \mathrm{~cm}$ high trending N. $60^{\circ}$ E. was found to be filled with hackberry seeds. This zone probably represents a mudcrack filling, indicating at least local ponding and drying periods. The great abundance of carbonate root casts suggest a heavy grass cover.

The poses of the peccary herd indicate that the peccaries died quietly and that their bodies were buried quickly. There is no evidence of the death pose-the head thrown back-that results from desiccation of the large tendons of the back of the neck when the body lies exposed on the surface. From the poses, death could have occurred in one of three ways: smothering in a duststorm, freezing, or smothering beneath the slumping of a vertical or overhanging loess bluff. The third possibility was suggested to Whitmore by Cornelia C. Cameron, who is familiar with sudden and heavy slumps of loess in Iowa. The Hickman peccaries may have died in a gully that was subsequently filled; perhaps they had taken refuge in the lee of an overhanging part of the gully wall which caved in on them. This would have preserved the skeletons in undisturbed position. Modern peccaries seek shelter in burrows, sometimes sleeping in them (Hall and Dalquest, 1963). However, comparison of the strong orientation of the silt particles surrounding the Hickman peccary skeletons with the linear orientation of skeletons (figs. $6 \mathrm{~A}, 8$ ) tends to favor burial by windblown silt rather than by slumping.

Numerous observations of windblown silt (Péwé, 1951; Lugn, 1968) leave no doubt that dust burial can be rapid enough to cover animal bodies in such a way as to preserve them from predators. It is much less certain, however, that a herd can be smothered in a duststorm and remain in the relaxed natural posture in which the Hickman herd and other herds of Platygonus compressus were found. We have made an extensive, though not exhaustive, search of travel literature on central Asia and Arabia and have found no reports of smothering of animals in the many duststorms and sandstorms that have been described in those areas. Heat, cold, and drought are frequently cited as causing localized and, sometimes, mass mortality, which emphasizes the lack of citation of dust as a cause of death. Possibly, however, dust inhalation can be a contributary cause of death when coupled with immobilization because of cold. If extreme weather conditions rendered a Platygonus compressus herd comatose, or dead, it could be quickly covered with dust. The way in which this might happen was graphically described by Hedin (1905, p. 48) : "You have only to crouch down with your back to the wind, and you are at once wellnigh suffocated by the amount of dust and sand that accumulates in the eddy formed by the shelter of your own body." Hay $(1923$, p. 214, 216) and Clarke (1916, p. 34-35) suggested that peccary herds were overcome by cold.

In Altonian time the prevailing southwesterly wind combined with the intermittent northwesterly (figs. $6,8)$ wind swept across the seasonally dry mudflats, picking up silt and depositing it as a blanketlike mantle on the low hills east of the flood plain. It was probably during one of the northwesterly duststorms, accompanied by a drop in temperature, that the peccaries met their sudden death and were buried. Their linear arrangement and inclined positions (fig. 9) suggest that they were walking up a trail away from the river with their backs to the wind when they became cold, crouched down, and were overwhelmed.

\section{REFERENCES CITED}

Browne, R. G., and Bruder, P. M., 1963, Pleistocene Mollusca from the loesses of Kentucky: Sterkiana, no. 11, p. 53-57.

Case, E. C., 1921, Something about the paleontological collections in the University: The Michigan Alumnus, v. 27, p. 292-300.

Chapman, F. M., 1936, White-lipped peccary: Natural History, v. 38, p. $408-413$.

Clarke, J. M., 1916, Report on the geological survey, Paleontology, in Twelfth Report of the Director of the State Museum and Science Dept.: New York State Mus. and Science Service Bull. 187, p. 33-39.

Finch, W. I., 1971, Geologic map of part of the Hickman quadrangle, Fulton County, Kentucky and Mississippi County, Missouri: U.S. Geol. Survey Geol. Quad. Map GQ-874.

Frye, J. C., Glass, H. D., and Willman, H. B., 1962, Stratigraphy and mineralogy of the Wisconsinan loesses of Illinois: Illinois Geol. Survey Circ. 334, 55 p.

Frye, J. C., and Willman, H. B., 1960, Classification of the Wisconsinan Stage in the Lake Michigan glacial lobe: Illinois Geol. Survey Circ. 285, 16 p.

1963, Development of Wisconsinan classification in Illinois related to radiocarbon chronology: Geol. Soc. America Bull., v. 74, no. 4, p. 501-505.

Frye, J. C., Willman, H. B., Rubin, Meyer, and Black, R. F., 1968, Definition of Wisconsinan Stage: U.S. Geol. Survey Bull. 1274-E, 22 p.

Gazin, C. L., 1938, Fossil peccary remains from the upper Pliocene of Idaho: Washington Acad. Sci. Jour., v. 28, no. 2 , p. 41-49.

Goddard, E. N., chm., and others, 1948, Rock-color chart: Washington, Natl. Research Council, 6 p. 
Guilday, J. E., Hamilton, H. W., and McCrady, A. D., 1971, The Welsh Cave peccaries (Platygonus) and associated fauna, Kentucky Pleistocene: Carnegie Mus. Annals, v. 43 , art. 9 , p. 249-320.

Hall, E. R., and Dalquest, W. W., 1963, The mammals of Veracruz: Kansas Univ. Mus. Nat. History Pub., v. 14, no. 14, p. $165-362$.

Hartnagel, C. A., and Bishop, S. C., 1922, The mastodons, mammoths, and other Pleistocene mammals of New York State: New York State Mus. Bull., nos. 241-242, 110 p.

Hay, O. P., 1923, The Pleistocene of North America and its vertebrated animals from the States east of the Mississippi River and from the Canadian provinces east of longitude $95^{\circ}$ : Carnegie Inst. Washington Pub. 322, $499 \mathrm{p}$. 1924, The Pleistocene of the middle region of North America and its vertebrated animals: Carnegie Inst. Washington Pub. $322 A, 385$ p.

Hedin, S., 1905, Lop-nor, v. 2 of Scientific results of a journey in central Asia, 1899-1902: Lithographic Inst., General Staff, Swedish Army, Stockholm, 716 p.

Hibbard, C. W., and Taylor, D. W., 1960, Two late Pleistocene faunas from southwestern Kansas: Michigan Univ. Mus. Paleontology Contr., v. 16, no. 1, p. 1-223.

Hoare, R. D., Coash, J. R., Innis, Charles, and Hole, Thornton, 1964, Pleistocene peccary Platygonus compressus Le Conte from Sandusky County, Ohio: Ohio Jour. Sci., v. 64 , no. 3, p. 207-214.

James, W. R., and Jones, T. A., 1969, Analysis of bimodal orientation data: Math. Geology, v. 1, no. 2, p. 129-135.

Jones, T. A., 1967, Estimation and testing procedures for circular normally distributed data: Office of Naval Research, Geography Branch, Tech. Rept. 3, ONR Task No. 388-078, Contract Nonr-1228(36), 61 p.

1968, Statistical analysis of orientation data: Jour. Sed. Petrology, v. 38 , no. 1, p. 61-67.

Kirkpatrick, R. D., and Sowls, L. K., 1962, Age determination of the collared peccary by the tooth-replacement pattern: Jour. Wildlife Management, v. 26, no. 2, p. 214-217.

Klippart, J. H., 1875, Discovery of Dicotyles (Platygonus) compressus, Le Conte [at Columbus, Ohio]: Am. Assoc. Adv. Sci. Proc., v. 23, pt. 2, p. 1-6.

Le Conte, J. L., 1848, Notice of five new species of fossil mammalia from Illinois: Am. Jour. Sci., ser. 2, v. 5, p. 102-106.

Leidy, Joseph, 1853, A memoir on the extinct Dicotylinae of America: Am. Philos. Soc. Trans., n. s., v. 10, p. 323-343.

1889, On Platygonus, an extinct genus allied to the peccaries: Wagner Free Inst. Sci. Trans., v. 2, p. 41-50.

Leighton, M. M., 1960, The classification of the Wisconsin glacial stage of north Central United States: Jour. Geology, v. 68 , no. 5, p. 529-552.

Leighton, M. M., and Willman, H. B., 1949, Late Cenozoic geology of Mississippi Valley, southeastern Iowa to central Louisiana, in Itinerary of [2d Pleistocene] field conference, June 12-25, 1949: Urbana, Ill., State Geologists, $86 \mathrm{p}$.

1950, Loess formations of the Mississippi Valley: Jour. Geology, v. 58, no. 6, p. 599-623: reprinted as Illinois Geol. Survey Rept. Inv. 149.

Leopold, A. S., 1959, Wildlife of Mexico-The game birds and mammals: Berkeley, California Univ. Press, 568 p.

Lewis, G. E., 1970, New discoveries of Pleistocene bisons and peccaries in Colorado, in Geological Survey research 1970: U.S. Geol. Survey Prof. Paper 700-B, p. B137B140.

Lugn, A. L., 1968, The origin of loesses and their relation to the Great Plains in North America, in Schultz, C. B., and Frye, J. C., eds., Loess and related eolian deposits of the world-Internat. Assoc. Quaternary Research, 7th Cong., Boulder-Denver, Colo., 1965, Proc., v. 12: Lincoln, Nebraska Univ. Press, p. 139-182.

Matalucci, R. V., Shelton, J. W., and Abdel-Hady, M., 1969, Grain orientation in Vicksburg loess: Jour. Sed. Petrology, v. 39 , no. 3 , p. 969-979.

Morgan, Randy, 1967, Fossil bones in gravel pit may be 40,000 years old: Paducah, Ky., Sun-Democrat, v. 90, no. 122 , p. 1, 2, May 22.

National Research Council, Committee for the Study of Eolian Deposits, 1952, Pleistocene eolian deposits of the United States, Alaska, and parts of Canada [Map]: Geol. Soc. America, scale $1: 2,500,000$.

Peterson, O. A., 1914, A mounted skeleton of Platigonus leptorhinus in the Carnegie Museum: Carnegie Mus. Annals 9 , p. 114-117.

Péwé, T. L., 1951, An observation on wind-blown silt: Jour. Geology, v. 59, no. 4, p. 399-401.

Potter, P. E., and Pettijohn, F. J., 1963, Paleocurrents and basin analysis: New York, Academic Press, $296 \mathrm{p}$.

Ray, C. E., Denny, C. S., and Rubin, Meyer, 1970, A peccary, Platygonus compressus Le Conte, from drift of Wisconsinan age in northern Pennsylvania: Am. Jour. Sci., v. 268 , no. 1 , p. $78-94$.

Rubin, Meyer, and Taylor, D. W., 1963, Radiocarbon activity of shells from living clams and snails: Science, v. 141, no. 3581 , p. 637 .

Schultz, L. G., 1964, Quantitative interpretation of mineralogical composition from X-ray and chemical data for the Pierre Shale: U.S. Geol. Survey Prof. Paper 391-C, 31 p.

Siegel, Sidney, 1956, Nonparametric statistics for the behaviorial sciences: New York, McGraw-Hill Book Co., 312 p.

Simpson, G. G., 1949, A fossil deposit in a cave in St. Louis [Mo.]: Am. Mus. Novitates 1408, 46 p.

Smith, G. D., 1942, Illinois loess-variations in its properties and distribution, a pedologic interpretation: Illinois Univ. Agr. Expt. Sta. Bull. 490, p. 139-184.

Sowls, L. K., 1961, Hunter-checking stations for collecting data on the collared peccary (Pecari tajacu): North American Wildlife and Nat. Resources Conf., 26th, trans., p. 496-505.

1966, Reproduction in the collared peccary (Tayassu tajacu) in Comparative biology of reproduction in mammals: London and New York, Academic Press, Symposia, Zool. Soc. London, no. 15, p. 155-172.

Stephens, M. A., 1962, Exact and approximate tests for directions, I : Biometrika, v. 49 , p. 463-477.

1964, The testing of unit vectors for randomness: Am. Statistical Assoc. Jour., v. 59, p. 160-167.

Sullivan, B. M., Spiker, Elliott, and Rubin, Meyer, 1970, U.S. Geological Survey radiocarbon dates XI : Radioc_rbon, v. 12 , no. 1 , p. 319-334.

Wagner, George, 1903, Observations on Platygonus compressus Le Conte: Jour. Geology, v. 11, p. 777-782.

Williston, S. W., 1894, Restoration of Platygonus: Kansas Univ. Quart., v. 3, no. 1, p. 23-39. 